Article

\title{
What Characteristics Help Entrepreneurs 'Make It' Early on in Their Entrepreneurial Careers? Findings of a Regional Study from Romania
}

\author{
Elena-Loreni Baciu ${ }^{1, *}$, Delia Vîrgă ${ }^{2}$ and Theofild-Andrei Lazăr ${ }^{1} \mathbb{D}$ \\ 1 Department of Social Work, The Research-Action Centre on Discrimination and Social Inclusion, \\ Faculty of Sociology and Psychology, West University of Timișoara, 300223 Timișoara, Romania; \\ theofild.lazar@e-uvt.ro \\ 2 Department of Psychology, Faculty of Sociology and Psychology, West University of Timisoara, \\ 300223 Timișoara, Romania; delia.virga@e-uvt.ro \\ * Correspondence: elena.baciu@e-uvt.ro; Tel.: +40-256-592-331
}

Received: 30 May 2020; Accepted: 17 June 2020; Published: 19 June 2020

\begin{abstract}
Entrepreneurship plays an essential role in modern urban growth and development. Successful businesses engage more growth potential, but also failed ones produce significant losses. Therefore, in order to reduce losses, it becomes important to understand what contributes to entrepreneurial success. Based the character-based approach, the current study considers the entrepreneur a critical agent for the survival and success of the business, and aims to examine the differences between successful and unsuccessful entrepreneurs in terms of human capital and personal characteristics. The sample consisted of 123 Romanian nascent urban entrepreneurs who participated in a government sponsored entrepreneurial support program and competed for a subsidy to start their business. A positive outcome in the competition (achieved by 39 study participants) was considered as entrepreneurial success. Based on the competition outcome, we split the sample in successful and unsuccessful entrepreneurs and analyzed the differences between the two groups from the perspective of human capital and personal characteristics. In terms of human capital (education, professional experience, age, and sex), the results showed small differences between the successful and unsuccessful entrepreneurs in the sample. In terms of personal characteristics, compared to their unsuccessful counterparts, the successful entrepreneurs registered increased levels of entrepreneurial self-efficacy, and of problem-solving confidence, higher levels of trust in their capacity of taking up challenges, increased levels of adaptive assertiveness, and a greater confidence in their ability to control their entrepreneurial behaviour. No significant differences were recorded for the need for autonomy, tolerance of ambiguity, risk-taking propensity, impulsivity, and interpersonal reactivity. The findings indicate that the personal characteristics of entrepreneurs may have different influences on their success, depending on the stage in their entrepreneurial career.
\end{abstract}

Keywords: entrepreneurial success; nascent entrepreneurs; urban entrepreneurs; character-based approach

\section{Introduction}

Various investigations into the relationship between entrepreneurship and urban development have concluded that there is a strong connection between the two dimensions [1,2]: Entrepreneurship plays an essential role in modern urban growth [3], and correlates strongly with employment increase in urban areas [3,4]. A recent analysis of data from 22 European Union member states found out that urban regions with high levels of economic growth and diversity of economic activities show higher levels of opportunity-motivated (as opposed to necessity-motivated) entrepreneurial activities [5]. 
As such, urban enterprises not only become drivers of urban growth, but also of innovation and experimentation, which engage urban areas in virtuous circles of improvement and development for newer and better opportunities. Among all types of businesses, small and medium-sized enterprises (SMEs) are the dominant form of business organization in most countries, generating between $55 \%$ and $70 \%$ of the gross domestic product (GDP) and between $65 \%$ and $95 \%$ of total employment [6]. Thus, SMEs play a key role in generating economic growth, job creation, and sustainable development. This is one of the main reasons for which an increasing number of governments use subsidies to encourage entrepreneurial initiatives to enhance the development of urban areas $[7,8]$.

However, given the high rate of failure of newly established businesses and the losses it generates to all parties involved, entrepreneurs and investors alike [9-11], it becomes essential to improve our understanding of why some businesses are more successful and more durable than others.

The character-based approach $[9,12]$ in the study of entrepreneurial success points to the inextricable link between the characteristics of entrepreneurs (expressed through their personality structure and human capital) and the track record of their businesses. According to this approach, the personality traits of the entrepreneurs are viewed as causes of mental and behavioral processes that influence business decisions [13]. Thus, they are very significant for the success of their enterprise [14,15] especially in what regards SMEs: The smaller the business, the greater the impact of the entrepreneur's personality on its success [9]. Therefore, it becomes important to understand what personal characteristics define the entrepreneurs who engage in successful entrepreneurial activities, especially in the light of increasing the use of subsidies to stimulate development and growth in urban areas.

The current paper aims to bring a contribution in this area, by taking a look at the characteristics of the main actors of the entrepreneurial activity: The entrepreneurs. In doing so, we use the character-based approach in analyzing the differences, in terms of personal characteristics, of entrepreneurs that are in the early stage of their entrepreneurial career and who have managed to secure (or not) the necessary funding for their business idea. The novelty of our approach is provided by the particular period of the entrepreneurial process that makes the object of our study: The key moment in which the entrepreneurs enacted their entrepreneurial potential, thus changing their status from potential to actual entrepreneur.

The Section 2 of the article highlights the key concepts of the theoretical framework used and the methodology of the investigation. The Section 3 presents the results of the study, highlighting the differences in terms of human capital and personality structure between successful and unsuccessful urban nascent entrepreneurs participating in the investigation, and integrates them in the larger context of similar studies. The Section 4 discusses the main findings of the study and their possible interpretations. The Section 5 indicates the limitations of the study and how they could reflect on the interpretation of the findings.

\section{Materials and Methods}

\subsection{The Theoretical Framework of the Study}

\subsubsection{Entrepreneurs and Nascent Entrepreneurs}

There is a large variety of approaches in defining entrepreneurial activities and entrepreneurs that ultimately point to the importance of various aspects of personality that 'make' an entrepreneur.

King [16] equals entrepreneurial activity with the functions of uncertainty bearing, innovation bringing, and capital provision. Thus, in his vision, the entrepreneur is the person who organizes, leads, and undertakes the risk for a business enterprise. This involves a retrospective definition of entrepreneurship: A person is identified as an entrepreneur as a result of some activities that he/she undertook (ex-post), as opposed to presenting the capacity or potential for implementing such activities (ex-ante). 
While some authors are very generous with the concept of entrepreneurship and assign this function to various types of undertakings, including self-employment and the exercising of liberal professions [17], others are particular about the conditions required to qualify as such. For example, some authors consider entrepreneurial undertakings only those types of entities that have at least one other employee besides the owner of the business [9]. Other authors consider that, since entrepreneurship can be the attribute of both managers and owners of SMEs [12,13], the creation of a small private enterprise could not be regarded as entrepreneurial activity in itself, unless it is characterized by novelty and creativity.

There are various authors $[13,18,19]$ that assign entrepreneurial functions to those persons that identify opportunities and create new businesses or companies, which they later develop. This perspective associates entrepreneurship with attitudes and behaviors like value creation, exploitation of opportunities, and innovation. Akhtar et al. [20] assess the recurrent themes in the literature regarding entrepreneurship and observe that the most commonly listed involve recognition and exploitation of opportunities, innovation and change, and value creation. Since individuals differ in their tendencies and abilities to engage in each of these tasks, the entrepreneurial activity becomes a function of the psychological composition of individuals.

While the perspectives on identifying and defining the entrepreneurs use a purely retrospective approach, the theoretical perspective regarding nascent entrepreneurs combines retrospective and prospective methods, since, for this specific category, the entrepreneurial undertaking has yet to be completed. Thus, generally speaking, nascent entrepreneurs refer to those persons who are in the process of starting a business [21], and who have engaged in activities meant to lead to the desired result. However, the business has not been established yet [22]. Thus, what is objectively identifiable to this category is (1) the presence of the desire to start a new business and (2) the involvement in concrete activities, meant to lead to the achievement of this objective [22]. Regarding the second condition, some authors consider that, in order for it to be fulfilled, the person must be involved in at least two concrete activities meant to support the application of the entrepreneurial intention (such as looking for a headquarters or the necessary equipment, developing a business plan, making some investments, or organizing a team) [23] (p. 43).

In agreement with the perspectives presented above [22,23], in the current study, we have included in the sample, as nascent entrepreneurs, persons who fulfilled the following conditions:

1. Have expressed the desire to start a new business;

2. Acting on this desire, they got involved in at least two concrete activities supporting their objective: drew up a business plan and attended a training program in entrepreneurship.

\subsubsection{Entrepreneurial Intention}

Liñán and Chen [24] approach entrepreneurial activity as a process that develops in time. In this process, the entrepreneurial intention is the first step within the long evolvement process of business creation. Thus, because the intention is the best and only predictor of behavior [24,25], the entrepreneurial intention becomes the fundamental predecessor to the actual implementation of entrepreneurial behaviors.

Thus, from a theoretical standpoint, entrepreneurship represents a premeditated activity and involves a process with various stages, the first of which consists of the crystallization of entrepreneurial intention.

This intention can be influenced by several factors, among which some are individual, such as the entrepreneurs' needs, values, desires, customs, and beliefs [24,26]. The cognitive variables that influence entrepreneurial intention are identified as 'motivational antecedents' [27]. Therefore, favorable antecedents contribute to fueling entrepreneurial intention [28].

Also, there is a host of contextual or 'situational' factors that can influence entrepreneurial intention [24,29], through modeling the entrepreneur's attitudes regarding the entrepreneurial activity 
and its desirability [24]. Examples in this category include time limitations, task difficulty, favorable or unfavorable legislative climate, cultural, or social influences.

\subsubsection{Entrepreneurial Success}

The approaches to defining and measuring success in entrepreneurial activities vary among studies. Some authors have equaled 'entrepreneurial success' with 'business success' and, as such, assessed it exclusively through the profits or financial performance of the business $[9,12,17,18,30]$.

Other authors have included dimensions that refer to the idea of 'growth' in the measurement of entrepreneurial success: Increase in the number of employees; rise in sales, profitability, or market share $[9,12,31-33]$.

A third approach focuses on the core function the entrepreneurs have in the building, developing, and evaluating the success of their businesses and acknowledges that success is experienced subjectively $[13,20]$ and based, among others, on the congruence between expectations and results [17]. According to this latter perspective, unsuccess also becomes less objectively observable: For example, according to this approach, business closure does not equal entrepreneurial failure but could be strategic action taken by the entrepreneur [21,34-36].

Combinations between these approaches are also possible. For example, in one study focused on assessing the capacity of prediction of entrepreneurial success through the character-based approach [9], the authors evaluated entrepreneurial success through two dimensions: Employment status of the entrepreneurs sometime after they set up their business (if the entrepreneurs kept their business owner status or if they gave up the business and became employees) and the number of employed persons by the newly found businesses.

Therefore, the entrepreneur is decisive not only for the success of the newly found business but also for its trajectory: The entrepreneur's characteristics and objectives are relevant in the development or closure of the business, and in the decision to expand or terminate of the entrepreneurial activity itself.

In the current study, we have assessed entrepreneurial success through a single categorical item, referring to the nascent entrepreneurs' objective outcome in trying to secure the necessary funding for starting their business. Although this conceptualization of success is not comprehensive of all the nuances of a thriving business, it does provide the advantages of being objectively verifiable and allows us to pin down in time the first successful enactment of the entrepreneurial potential, especially since the proportion of nascent entrepreneurs who do not manage to turn their business plan into an operational venture is very high $[37,38]$.

\subsubsection{The Characteristics of Successful Entrepreneurs}

The character-based approach posits that entrepreneurial success is greatly influenced by the human capital and the personality structure of the entrepreneurs, especially in the case of small businesses, with fewer employees $[9,39,40]$.

Both stable factors, such as personality traits [13,41], and malleable ones, such as self-efficacy [42], positive affect [43], risk-taking propensity [44], or locus of control [45] have proved to influence the cognitions, emotions, and behaviors of entrepreneurs, and therefore have been linked to the chances of survival and development of start-ups [42].

Regarding the effect of human capital, although a general agreement on how it influences entrepreneurial success has not been reached yet, the following four main characteristics of the entrepreneurs have been especially taken into consideration in the studies conducted so far:

(1) Education -is considered to have an important role in entrepreneurial activity, mainly because of the concrete outcomes it produces (knowledge, competences, values) [17]. Historically, the educational level of entrepreneurs (assessed through the number of years spent in school) has known a significant increase, both in raw numbers and as compared to that of the general population [17]. However, the evidence that generic human capital in the form of university 
education is beneficial for entrepreneurial success as measured by financial performance was weak [12].

(2) Professional experience- on the one hand, its function is very similar to that of education, and on the other hand, it could be the background for the crystallization of the entrepreneurial intention [17]. However, the empirical studies conducted so far have shown that the effects of professional experience in the field on the chances of success for newly established businesses can differ. Some authors [12,46] point out that professional experience can support the transition from nascent entrepreneur to the business owner, by equipping the nascent entrepreneurs with the skills to notice and assess the opportunities in the field, which gives their businesses better chances to survive [21,47]. On the contrary, other authors have identified a negative correlation between the professional experience and the actual starting of the new business, among nascent entrepreneurs [48].

(3) Age-the perspectives on the influence of age on the success of the entrepreneurial initiative also vary. Thus, while some authors argue that the businesses owned by younger entrepreneurs have a higher probability for growth [49], others claim that middle-aged entrepreneurs are more likely to grow their businesses than other age groups [50].

(4) Sex-there are authors that argue that the financial performance of firms led by women are superior to those led by men [12], while others claim the businesses led and owned by women tend to be smaller and have a lower probability for growth, compared with those led by men [51]. More recent research regarding inter-sex differences in the results of entrepreneurial activity, although still pointing out favorable results for men, claim that the differences are small [20].

Regarding the influence of the personality structure, research on the personality of entrepreneurs was mainly based on the five-factor model of personality. Researchers using this approach pointed to a particular personality profile associated with a person's intention to start a business: High Openness and Extraversion, Conscientiousness, and low Neuroticism [52]. A recent study conducted in Germany, which investigated the influence of personality on self-employment decisions, found that openness to experience, extraversion, and risk tolerance affect the decision to entry into self-employment and that that the overall Big Five traits explained $14 \%$ of the variance of the probability of being an entrepreneur, while risk attitudes alone explained another 8\% [53]. Additionally, extraversion predicted overall entrepreneurial success, while Agreeableness predicted Invention Entrepreneurship only [19].

However, as not all traits that describe the personality of the entrepreneurs can be located in the Big Five system [54,55], other global personality constructs rooted in specific theories have been applied as well to entrepreneurial research. Obschonka and Stuetzer [41] propose to approach the individual entrepreneurial personality as a dynamic system, that integrates basic traits (relatively stable and resilient to change) with more malleable ones, which represent characteristic adaptations and self-concept features that 'directly motivate, guide, and regulate entrepreneurial behavior' [41] (p. 222).

Caliendo and Kritikos [9] list four categories of personal characteristics of entrepreneurs that have been defined as useful in explaining the past success or predicting the future of a newly found business: (1) Motivational traits (like the need for achievement, internal locus of control, and need for autonomy); (2) cognitive skills (like problem-solving orientation, tolerance of ambiguity, creativity, and risk-taking propensity); (3) affective personality traits (like stress resistance, emotional stability, and level of arousal); and (4) social skills (like interpersonal reactivity, and assertiveness).

The analysis of these characteristics showed that the influence they have on the success of the entrepreneurial undertaking varies. For example, the finding that entrepreneurs are more prone to sensation seeking and taking risks compared to the general population $[9,18,56]$ could explain what drives them to take the extra step and enact their entrepreneurial intention. Other research findings showed that traits like the need for achievement, interpersonal reactivity, assertiveness, and problem-solving orientation are positively correlated with becoming an entrepreneur [9]. Also, high achievement motivation was pointed out as a prominent characteristic of successful entrepreneurs, oriented toward the growth of their enterprise [13]. Another finding showed that the cognitive 
bias resulting in optimism might have beneficial effects on entrepreneurial success assessed through financial performance [12].

Thus, based on the theoretical and empirical perspectives presented above, the current study posits that entrepreneurial success is sustained by certain characteristics of the entrepreneur.

Therefore, the main research question that guided this study was: What are the personal characteristics that distinguish successful entrepreneurs from the unsuccessful ones?

\subsection{Procedure}

The context of the current study was provided by the onset of a government support program for entrepreneurial start-up activities in the Western Region of Romania. The program was jointly funded by the European Union and the Romanian Government and encouraged the creation of new non-agricultural businesses in urban areas. The support services within by the program, although provided by various administrators, included the same main types of services: Entrepreneurial training programs, individual counseling services for the development of the business plan, and the funding of the business idea for selected participants. The selection was organized as a business plan competition, and the entrepreneurs who qualified for funding were eligible to receive subsidies of up to approx. 45,000 euro to start their business.

In agreement with the theoretical perspectives described above, we designed the study based on the processual approach [24] of entrepreneurial activity. We took into consideration the three main stages involved in the process of starting up a new business (Scheme 1).

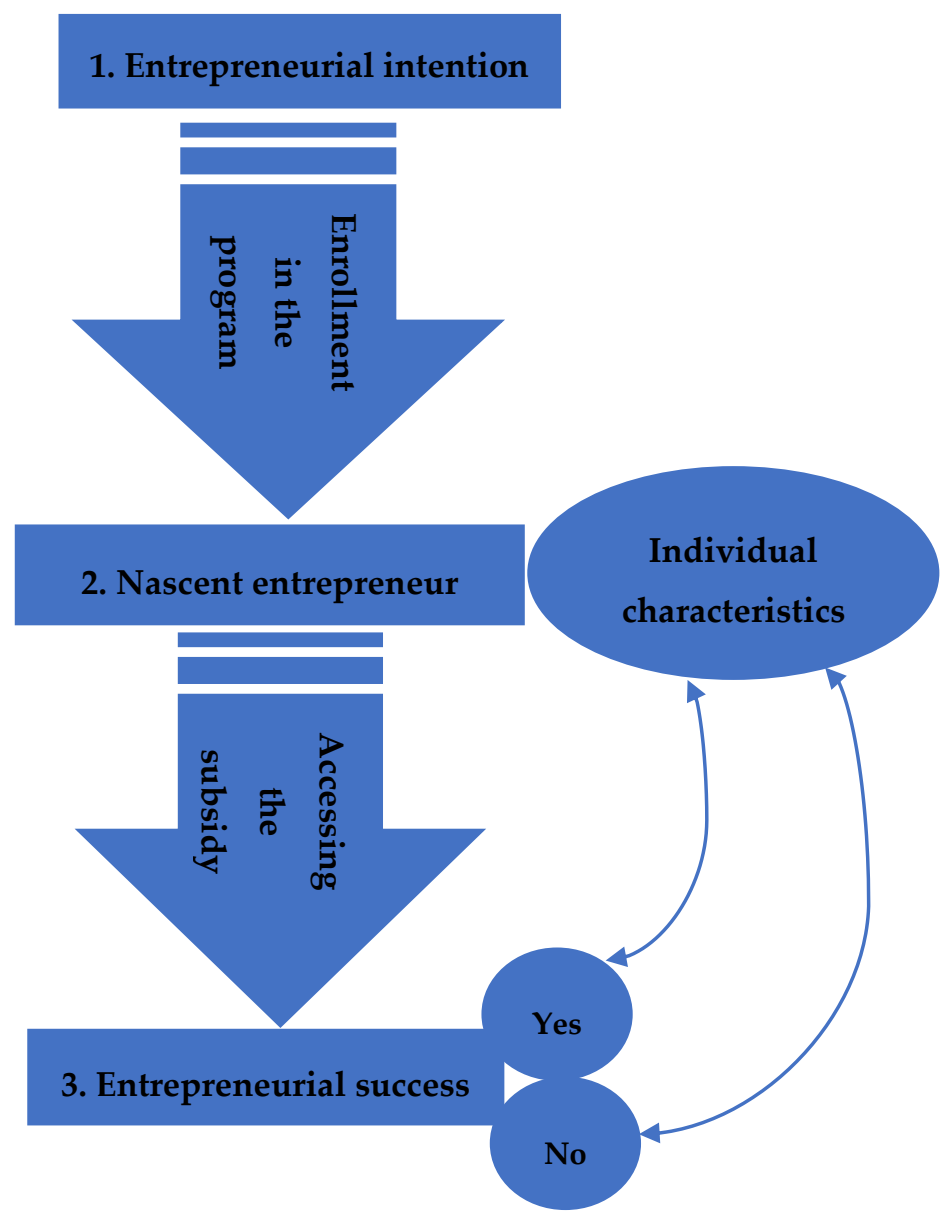

Scheme 1. The processual approach of entrepreneurial activity used in the current study. 
Therefore, starting from the central positioning of the entrepreneurial intention (EI) in triggering purposeful activities and entrepreneurial behaviors, we considered the enrolment in the entrepreneurial support program as a direct effect of previous crystallization of EI in all persons that have finalized the admission process in the program.

Immediately after the admission stage, all program beneficiaries got engaged in several mandatory pre-designed activities (entrepreneurial training programs, assisted development of a business plan, mentorship programs). Therefore, not only that they presented the intention to start up a business, but they also acted up upon that intention, which makes them compatible with the definition for nascent entrepreneurs presented earlier, based on other similar studies [22,23]. In this stage, the research team made an individual assessment of the nascent entrepreneurs from the perspective of their human capital and personality structure, following the principles of the character-based approach.

The last stage of the entrepreneurial process assessed in the study consisted of the organizing of the competition for accessing a subsidy for the implementation of the business plan drawn up during the previous stage. The competition consisted of two types of assessments, made by a panel of external jurors: Evaluation of the quality and feasibility of the business plan and an interview with the entrepreneurs, in which they presented the business idea and answered the questions of the jurors about the details of business operation. The participation in the competition represented a key moment in which the attendants enacted their entrepreneurial potential, through documenting and planning the business, developing their market strategy, and convincing the selection committee about the feasibility of their business plan.

Therefore, at this stage, the evaluation of entrepreneurial success was conducted using a single dichotomous item, regarding the outcome of the nascent entrepreneurs' efforts in securing the funding of their business plan. Although this conceptualization of entrepreneurial success does not capture all the complex nuances that describe the ability to survive and thrive in the economic environment, it encapsulates, nevertheless, three important aspects of the entrepreneurial process: (1) The decisive moment of the creation of the business; (2) the first successful enactment of the entrepreneurial potential; and (3) the transition from the status of nascent entrepreneur to actual business owner.

The originality and the novelty of this approach is two-fold:

- Ex-ante assessment: The personal characteristics of participants at the study were assessed early in their entrepreneurial career, before they set up their business (nascent entrepreneurs). Similar studies conducted before usually used an ex-post approach $[9,41]$;

- Homogeneity of the sample: All the entrepreneurs who participated in the study were at the same point in their entrepreneurial career (after they have decided to set up their business, but before they know the results of their endeavor), so they create, from this perspective, a reasonably homogenous group. Similar studies conducted before compared the traits of successful and unsuccessful entrepreneurs at different stages of their entrepreneurial career, or the traits of entrepreneurs and those of employees $[9,57,58]$.

\subsection{Instruments}

Drawing on the central assumption of the character-based approach regarding the influence of human capital and the personality structure of the entrepreneurs on the success of their business endeavors, we used data collection instruments that referred to both dimensions:

- For the collection of data regarding human capital, we used a questionnaire with 13 items, through which we collected data about the sex, age, educational attainment, and professional experience of respondents;

- For the collection of data regarding the personality structure, we used specific purpose scales applied in entrepreneurial research to measure specific constructs or traits.

For the assessment of motivational traits (need for achievement and need for autonomy), we used the following instruments: 
- Need for autonomy subscale of the Work-related Basic Need Satisfaction Scale-W-BNS, Dutch version [59]. The subscale has six items. The need for autonomy is the inherent desire of individuals to feel autonomous and to experience a sense of choice and psychological freedom when performing an activity [60], which is considered a good premise for the crystallization of EI. A higher score indicates an increased level of satisfaction of the need for autonomy at the current job, and therefore it would not indicate a supportive factor for the decision to launch a business [61] and the preoccupation for a detailed documentation and planning.

- Entrepreneurial Self-Efficacy-ESE [22], with 19 items. ESE is a construct that measures a person's level of trust in their capacity to set up successfully their own business. The instrument assesses 5 dimensions: (1) Searching, (2) planning, (3) mobilizing, (4) implementation-people, and (5) implementation-financial. Additionally, it includes a separate subscale that assesses the attitude toward entrepreneurship/launching a business. Higher scores indicate an increased level of trust in their capacity and a positive attitude toward entrepreneurship, which are expected to reflect on the entrepreneur's capacity to convince the panel juror about the feasibility of their business plan.

For the assessment of cognitive skills (problem-solving orientation, tolerance of ambiguity, and risk-taking propensity), we used:

- The Problem-Solving Inventory (PSI, Form A) [62-64], with 32 items. Applied problem solving is a very complex, often intermittent, goal-oriented sequence of cognitive, affective, and behavioral operations performed by the individual to adapt to internal or external demands that are often considered stressful $[62,65]$. Three factors are assessed: (1) Problem Solving Confidence-PSC, 11 items, (2) Approach-Avoidance Style-AAS, 16 items; and (3) Personal Control-PC, 5 items. Each factor provides an assessment of a specific dimension of the problem-solving style, and the overall score reflects an individual's overall evaluation of his or her problem-solving style. The results for all three factors and the total amount of PSI are continuous scores, not categorical. Lower scores for each factor (and for the total of PSI) are generally considered more functional.

- Tolerance of Ambiguity Scale-TAS [66], with 12 items. Tolerance of ambiguity is considered as the "tendency to perceive ambiguous situations as desirable" [67] (p. 29). TAS was developed by Herman et al. [66] based on a previous model of Budner [67]. A higher score on this scale indicates an increased capacity of tolerating ambiguous situations, which is extremely important in supporting the entrepreneur to adjust to the changes in the market environment.

- Risk Propensity Scale-RPS [68], with 7 items. The scale measures the general propensity of an individual toward risk-taking. Higher scores on RPS indicate an increased tendency to risk-taking. As mentioned previously, the entrepreneur is the actor who undertakes the main risks associated with setting up and operating the business.

For the assessment of affective personality traits (stress resistance and level of arousal), we used:

- The Psychological Capital Questionnaire-PsyCap [69], with 24 items. The questionnaire comprises four subscales, each with six items: Hope, Optimism, Resilience, and Self-efficacy. Scores can be calculated individually, for each subscale, or as a composite score. Higher scores indicate an increased tendency toward the dimension assessed. As previously mentioned, resilience and self-efficacy are important for facing the daily tasks associated with entrepreneurial activities, while optimism and hope impact the aspirations of the entrepreneurs and have been proven to impact the success of the business [12].

- The Barratt Impulsiveness Scale-BIS-11 [70], with 30 items. Impulsivity is defined as "a predisposition to rapid, unplanned reactions to internal or external stimuli, regardless of the negative consequences of these reactions on the subject or others" [71]. Higher scores indicate increased impulsiveness. Impulsive individuals are attracted to uncertain contexts, such as entrepreneurship, and are more likely to act despite this uncertainty [72]. 
For the assessment of social skills (interpersonal reactivity and assertiveness):

- The Interpersonal Reactivity Index-IRI, subscales Perspective Taking-PT, Empathic Concern-EC, and Personal Distress-PD [73], with 21 items. Empathy is a central component of normal social functioning, providing a base for pro-social behavior [74], socialization [75], and the increase of psychological wellbeing [76]. Scores are calculated individually for each subscale. Higher scores indicate an increased tendency toward the dimension assessed. An empathic entrepreneur is able to understand more about the clients' needs and thus better adjust to the market changes.

- Adaptive and Aggressive Assertiveness Scales-AAA-S [77], with 30 items. Assertiveness is the way to actively respond to interpersonal conflicts, to ensure that the personal needs are met [78]. The scale assumes two possible types of assertive response: (1) Aggressive assertiveness (denotes the use of coercive behaviors or violations of the rights of others, in the process of ensuring the satisfaction of needs); (2) adaptive assertiveness (reflects the use of socially acceptable behaviors, without violating the rights of others, in the process of ensuring the satisfaction of needs). Higher scores indicate an increased tendency toward the dimension assessed. Assertiveness has previously proved to have a significant positive impact on entrepreneurial success [9].

For the assessment of the entrepreneurial intention, we used 3 subscales of the Entrepreneurial Intention Questionnaire-EIQ [24]: Personal Attitude, Subjective Norm, and Perceived Behavioral Control. The questionnaire has 13 items in total and assesses the effort the subject is available to undertake to start the business. The main premise here is that the higher the effort the entrepreneurs are available to undertake, the better prepared they will be to face the challenges on the market.

\subsection{Participants}

The participants in the study were recruited among the registered beneficiaries of two of the administrators involved in the support program (one public entity and one private entity). The recruitment of the subjects was made based on the mailing lists provided by the two administrators, with all the enlisted participants in their database. All the persons in the mailing lists were invited to participate voluntarily in the study, by providing online answers to the questionnaire regarding human capital and the instruments meant to assess their personality traits, which had 207 items in total. The average duration for filling in all the required data was of about $120 \mathrm{~min}$. The participants received no incentives for taking part in the study and were informed about the purpose of the research. The individual results regarding the personality traits of the respondents were calculated according to the recommendations of the authors of each instrument and treated as confidential (only the research team members had access to them).

From a total of 600 persons who received the invitation, 123 provided complete answers that were validated for the study. Thus, the response rate among the potential subjects was 20.5 percent.

From the total number of subjects who provided validated answers, 44 percent were male, and 54 percent were female. The average age for the entire sample was of 34.39 years, with the youngest respondent being 20 years old and the oldest 61 years old. Regarding the highest level of education completed by the subjects in the sample, almost half of the respondents (49.6 percent) have completed a postgraduate study program (higher than bachelor level), approximately a quarter (26 percent) graduated university studies (bachelor level or equivalent) and the rest of them (24.4 percent) have graduated high school or similar (less than bachelor level). Regarding the overall professional experience, most of the respondents had a considerable level of such expertise (with almost 47.2 percent of the subjects having 10 or more years of experience and 16.3 percent having between 5 and 10 years of experience), while just a small part of the sample (11.4 percent) had less than one year or no professional experience at all.

For the respondents with validated questionnaires, the research team followed the results of the business plan competition, in order to assess if the entrepreneurs managed to get funding for their 
business idea. Thus, after the competition, a new (dichotomous) item was added in the database regarding the results registered by the individual participants in their entrepreneurial endeavor. A positive result in the competition (meaning the entrepreneur managed to get funding for the newly created business) was considered as entrepreneurial success, which was the case for 39 (31.7 percent) out of the total 123 participants at the study. Winning the competition meant they will certainly turn their business into an operation venture, which, in the light of the high proportion of nascent entrepreneurs who do not manage to do so [37,38], was seen as an important achievement at this stage in their entrepreneurial career.

After this stage of the process, the research focused on the comparative analysis of the personal characteristics of the members of the two groups (successful and unsuccessful entrepreneurs) in order to better understand what the key points are and where the they differ.

It is important to note here that the analysis of the personal characteristics was conducted by comparing the two groups between them, and not with other types of populations (i.e., employees, managers, or entrepreneurs at other stages of their career), which is an innovative approach compared to previous similar studies $[9,57,58]$, because we addressed a more homogenous group (nascent entrepreneurs) and thus eliminated a series of variations that could have impacted the findings in ways that are hard to trace.

\section{Results}

\subsection{Results Regarding the Differences in Human Capital among Successful and Unsuccessful Urban Nascent Entrepreneurs}

The comparative analysis of the education of the participants at the study, assessed through the highest level of educational attainment completed, shows no significant differences among the two groups, with almost equal representation of graduates of each type of level among both groups (Table 1 and Figure 1):

- Graduates of high school or similar (lower than Bachelor-BA) represent 23 percent of the subgroup of successful urban nascent entrepreneurs and 25 percent among the unsuccessful ones;

- Twenty-eight percent of the successful entrepreneurs and 25 percent of the unsuccessful ones are graduates of higher education-BA level; and

- Forty-nine percent of the successful entrepreneurs and 50 percent of the unsuccessful ones have graduated an educational program higher than BA level.

Table 1. Highest educational level completed * Outcome of the business plan competition.

\begin{tabular}{|c|c|c|c|c|c|}
\hline & & & \multicolumn{2}{|c|}{ Successful } & \multirow{2}{*}{ Total } \\
\hline & & & Yes & No & \\
\hline \multirow{6}{*}{$\begin{array}{l}\text { Highest educational } \\
\text { level completed }\end{array}$} & \multirow{2}{*}{ Lower than BA level } & Count & 9 & 21 & 30 \\
\hline & & $\%$ of Total & $7.3 \%$ & $17.1 \%$ & $24.4 \%$ \\
\hline & \multirow{2}{*}{ BA level } & Count & 11 & 21 & 32 \\
\hline & & $\%$ of Total & $8.9 \%$ & $17.1 \%$ & $26.0 \%$ \\
\hline & \multirow{2}{*}{ Higher than BA level } & Count & 19 & 42 & 61 \\
\hline & & $\%$ of Total & $15.4 \%$ & $34.1 \%$ & $49.6 \%$ \\
\hline \multirow{2}{*}{\multicolumn{2}{|c|}{ Total }} & Count & 39 & 84 & 123 \\
\hline & & $\%$ of Total & $31.7 \%$ & $68.3 \%$ & $100.0 \%$ \\
\hline
\end{tabular}

Accordingly, the success rates by educational attainment (Figure 2), calculated as the percentage of the persons in a certain educational attainment level group who have won the business idea competition, also shows small differences between groups: $34 \%$ success rate for the participants with BA level studies, 31\% for those with higher than BA level studies, and $30 \%$ for the entrepreneurs with lower than BA studies. 


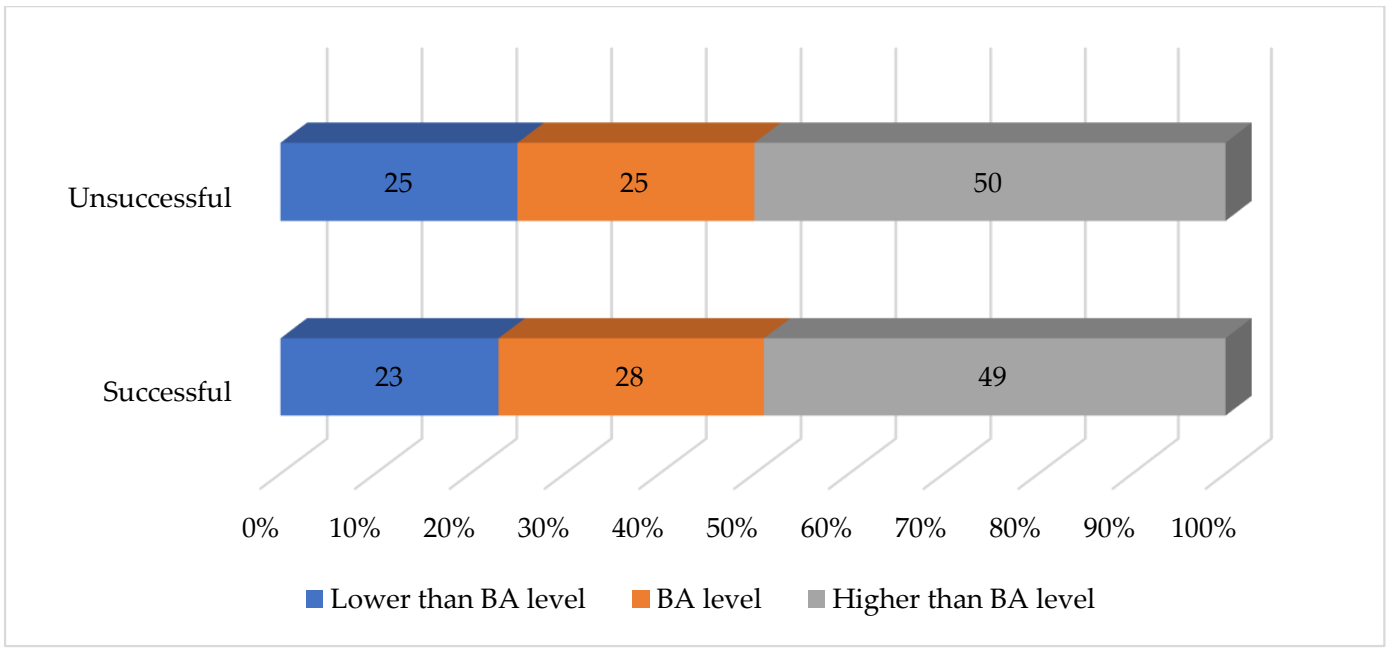

Figure 1. Highest level of educational attainment completed by the members of the two subgroups (percentage).

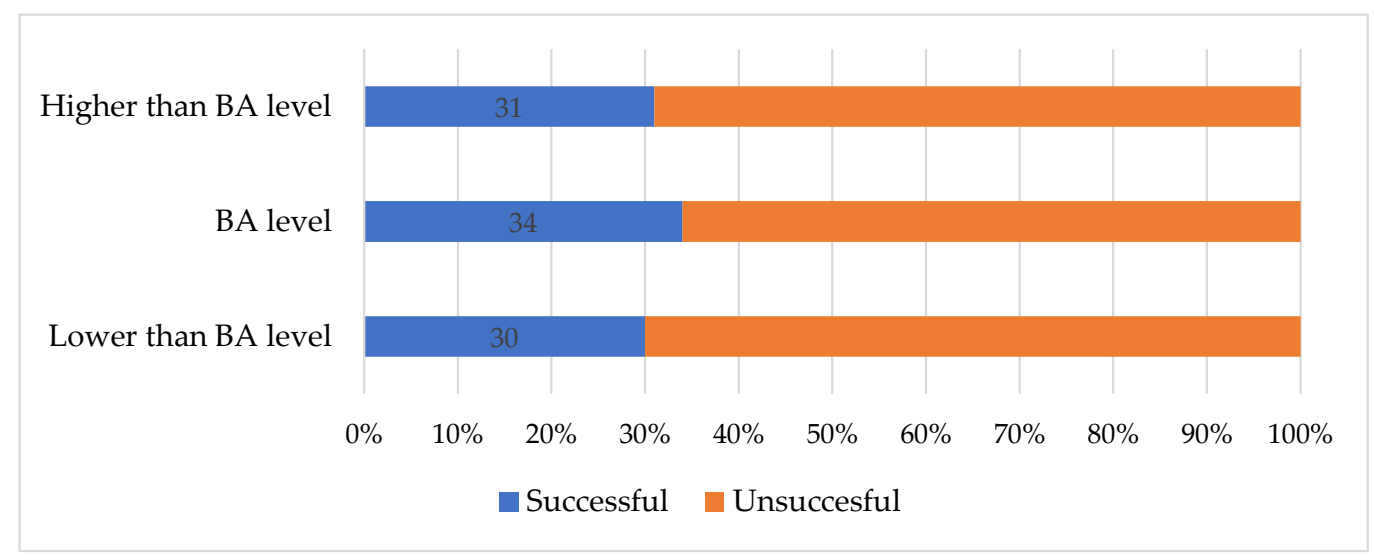

Figure 2. Success rate by educational attainment.

However, what is noticeable about the analysis of the educational attainment of the entrepreneurs from the sample is the fact that it confirms an observation made two and a half decades ago [17], regarding the fact that the entrepreneurs have a considerably higher level of education compared to the general population.

Thus, in 2018, the percentage of persons from the Western Region of Romania (the region where the participants at the study reside) with high educational attainment, the equivalent of ISCED (The International Standard Classification of Education) 5-8 levels, (BA level and higher) represented 15.7\% of the total population aged 25 to 64 [79]. Among the research sample, the persons who graduated ISCED 5-8 levels represent $75.6 \%$, which is almost five times higher compared to the general population (Figure 3).

Thus, a preliminary interpretation of these results would be that, although the level of education held by the urban nascent entrepreneurs participating in the study is consistently higher compared to that of the general population, the success rate registered in the competition by those with lower levels of educational attainment is similar to the one registered by those with higher levels of educational attainment. The interpretation of this finding has a close connection with the previously cited opinion about the weakness of evidence on the influence of generic human capital in the form of university education for entrepreneurial success, as measured by financial performance [12].

The comparative analysis of the professional experience held by the members of the two groups (Table 2 and Figure 4 ) shows that more than half (56.4\%) of the nascent entrepreneurs who have won 
the competition are persons with more than 10 years of professional experience, almost one-third of them (30.8 percent) hold one to five years of professional experience, while the rest (12.8 percent) have 5 to 10 years of professional experience.

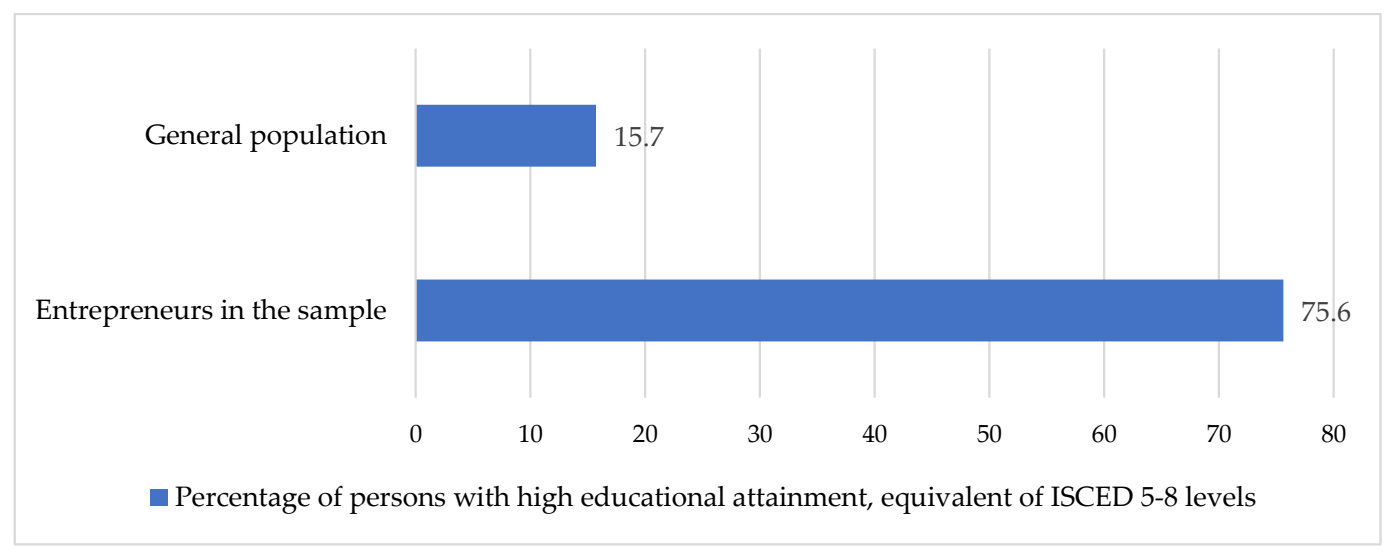

Figure 3. Percentage of persons with higher education (ISCED 5-8 levels) in the sample of entrepreneurs and in the general population from the area (comparison).

Table 2. Professional experience * Outcome of the business plan competition.

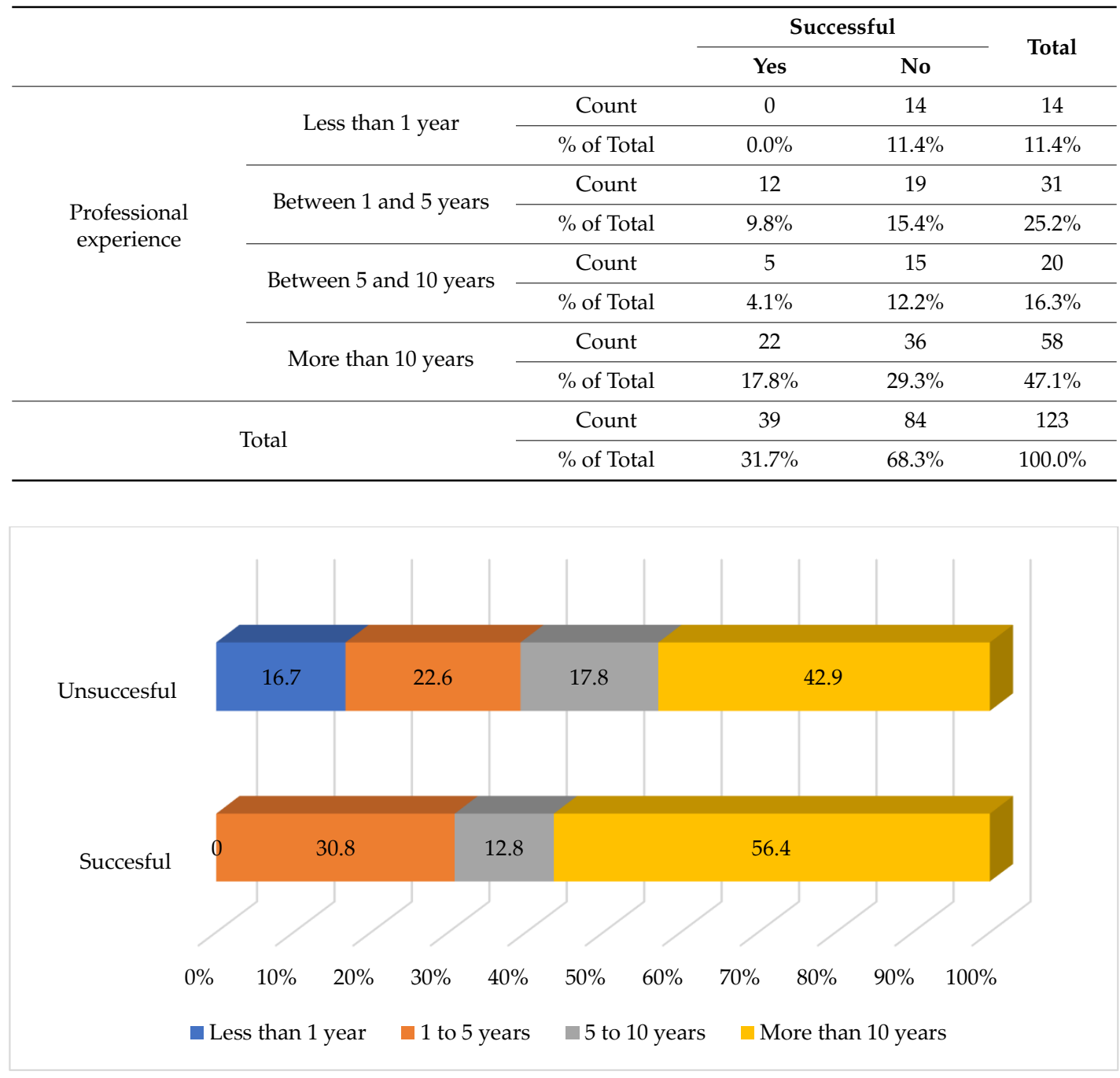

Figure 4. Professional experience among the members of the two subgroups (percentage). 
Also, a noteworthy observation is that none of the persons in the sample who have less than one year of professional experience have won the competition.

The success rate by length of professional experience (Figure 5), calculated as the percentage of the persons with a certain professional experience level who have won the business idea competition, shows that the highest success rate $(39 \%)$ is registered by the entrepreneurs with one to five years of experience, followed closely (38\%) by those with more than 10 years of experience. Only one in four entrepreneurs with 5 to 10 years of experience were successful in qualifying for the subsidy, while as mentioned earlier, none of the entrepreneurs with less than one year of experience has managed to win the competition.

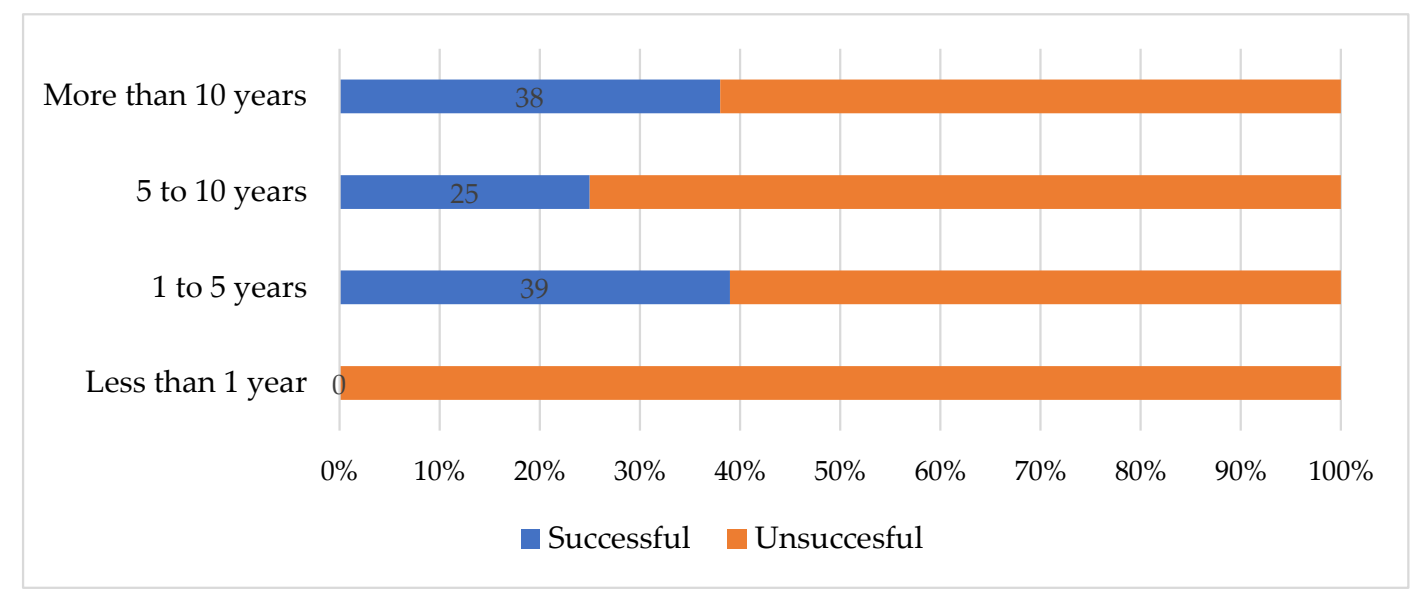

Figure 5. Success rate by length of professional experience.

The analysis of the average age for the two groups (Table 3) shows a slightly higher mean age of the participants at the study who have won the competition (mean age-35.38 years), compared to those who have not (mean age-33.93 years).

Table 3. The average age for the two groups.

\begin{tabular}{cccccc}
\hline & $\begin{array}{c}\text { Successful Outcome } \\
\text { in the Competition }\end{array}$ & $\mathbf{N}$ & Mean & Std. Deviation & Std. Error Mean \\
\hline \multirow{2}{*}{ Age } & Yes & 39 & 35.38 & 6.556 & 1.050 \\
\cline { 2 - 5 } & No & 84 & 33.93 & 10.193 & 1.112 \\
\hline
\end{tabular}

Additionally, when distributing the nascent entrepreneurs participating in the study in four age categories ( 25 or under, 26 to 35,36 to 45 , and over 45 years old), we can notice that two-thirds of them (67.5 percent) are found in the second and third category (Table 4).

Accordingly, most of the entrepreneurs who have won the competition are also found in these two age groups (Figure 6). Thus, almost half (48.7\%) of the successful nascent entrepreneurs are aged 26 to 35, while more than one-third of them are aged 36 to 45 . Those that are aged over 45 represent $10.2 \%$ of the winners of the competition, while the youngest group (aged 25 or under) represents only $5.1 \%$ of those with a successful application.

Thus, the success rate by age group (Figure 7), calculated as the percentage of the persons in a certain age group who have won the business idea competition, shows that although the entrepreneurs aged 26 to 35 represent almost half $(48.7 \%)$ of those who have won the competition, their success rate is lower when compared to that of the participants aged 36 to 45 ( $38 \%$ vs. $42 \%$ ).

The lowest success rate $(9 \%)$ is recorded among the youngest group, aged 25 or under.

These findings are in line with the results of similar studies, which recorded good potential for success both among younger entrepreneurs [49] and among middle-aged ones [50]. 
The majority of the nascent urban entrepreneurs that participated in the study and won the business plan competition (61.5 percent) were female (Table 5).

Table 4. Age category * Outcome of the business plan competition.

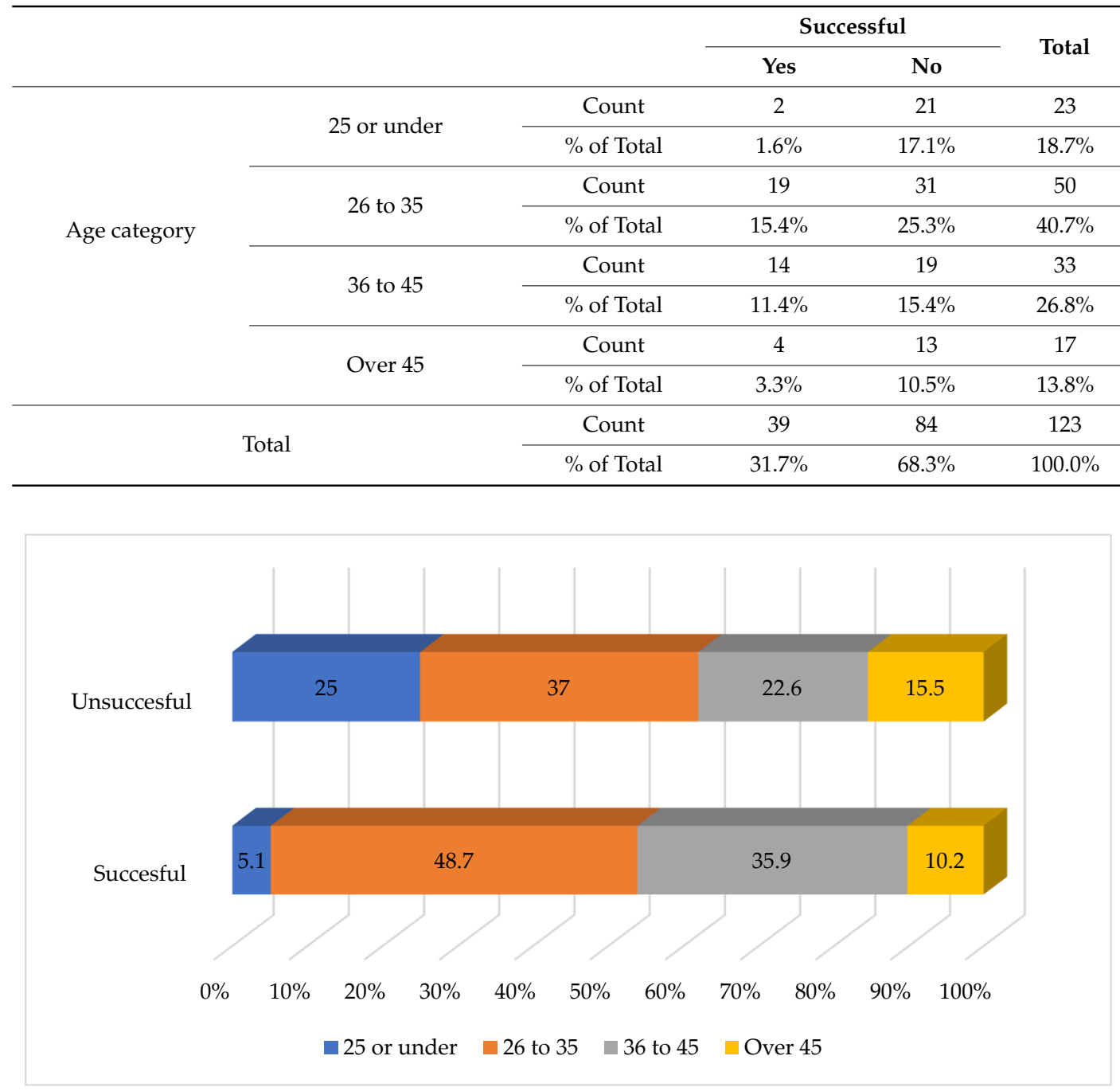

Figure 6. Age category of the members of the two subgroups (percentage).

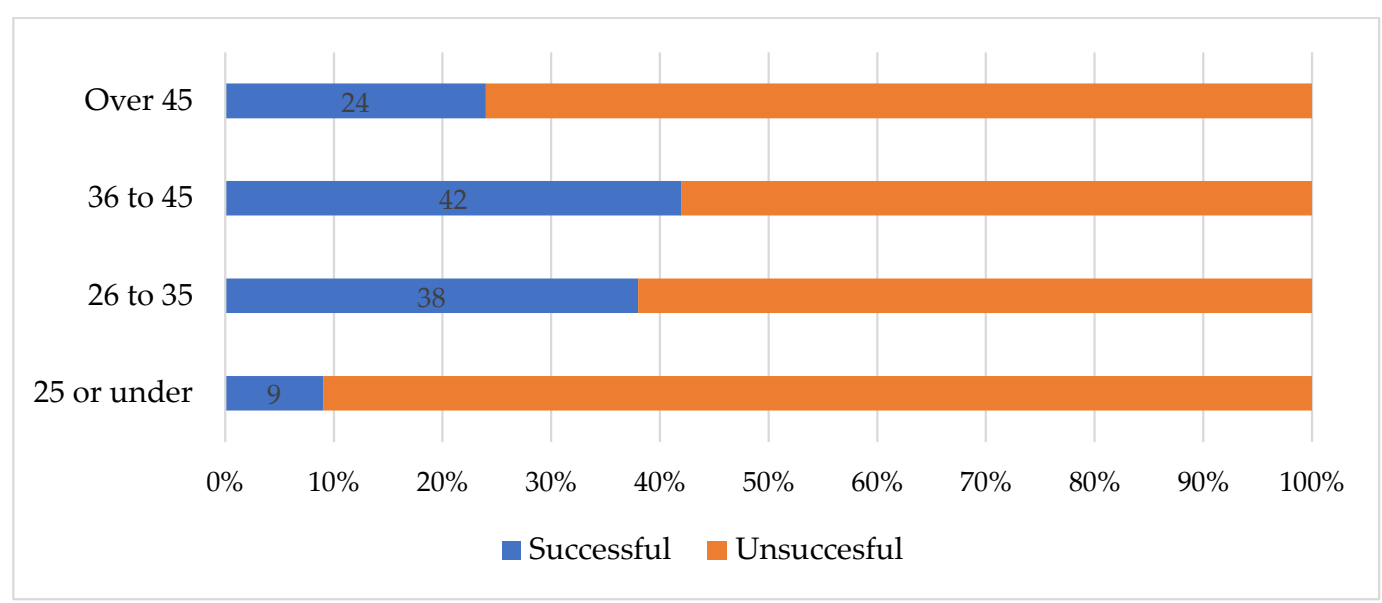

Figure 7. Success rate by age group. 
Table 5. Sex * Outcome of the business plan competition.

\begin{tabular}{|c|c|c|c|c|c|}
\hline & & & \multicolumn{2}{|c|}{ Successful } & \multirow{2}{*}{ Total } \\
\hline & & & Yes & No & \\
\hline \multirow{4}{*}{ Sex } & \multirow{2}{*}{ Male } & Count & 15 & 39 & 54 \\
\hline & & $\%$ of Total & $12.2 \%$ & $31.7 \%$ & $43.9 \%$ \\
\hline & \multirow{2}{*}{ Female } & Count & 24 & 45 & 69 \\
\hline & & $\%$ of Total & $19.5 \%$ & $36.6 \%$ & $56.1 \%$ \\
\hline & \multirow{2}{*}{ Total } & Count & 39 & 84 & 123 \\
\hline & & $\%$ of Total & $31.7 \%$ & $68.3 \%$ & $100.0 \%$ \\
\hline
\end{tabular}

Due to the fact that the percentage of females in the total sample is higher than that of males (56 vs. $44 \%$ ), the majority of those who did not win the competition were also females (53.6\%) (Figure 8).

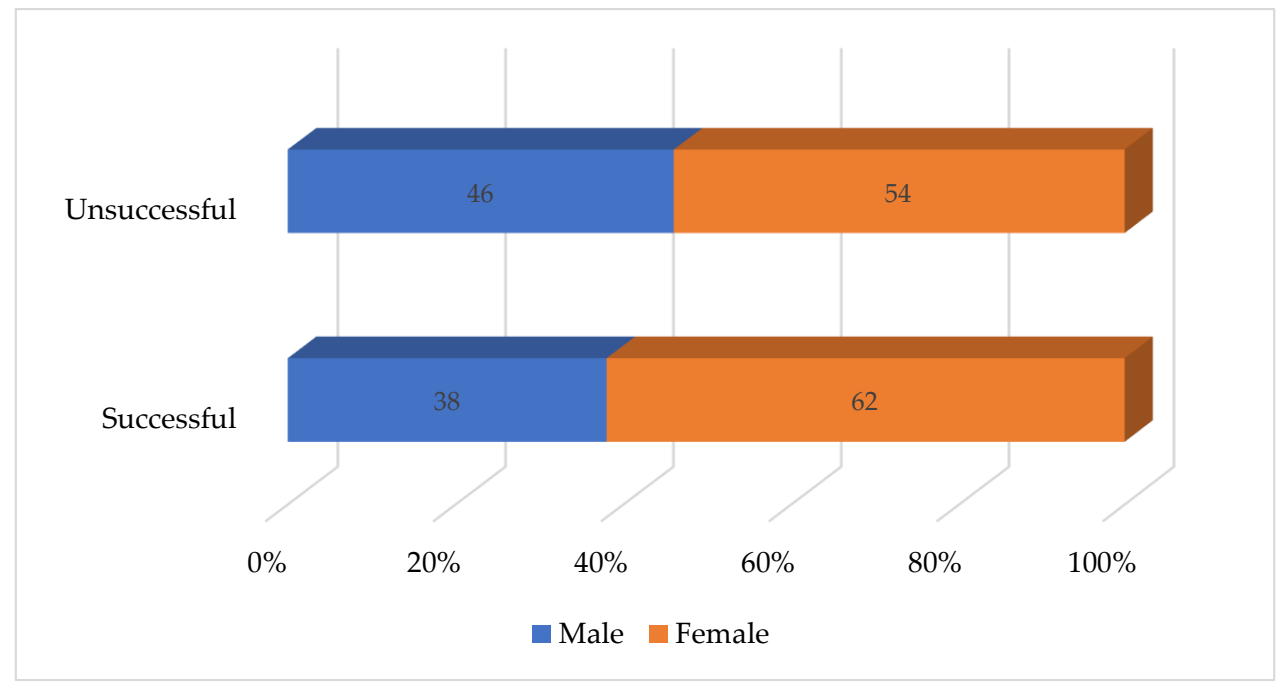

Figure 8. Structure of the two subgroups by sex (percentage).

However, when analyzing the success rate by sex, among the participants in the competition (Figure 9), we notice a slightly higher success rate among female attendants $(34.8 \%)$ than among male attendants $(27.8 \%)$.

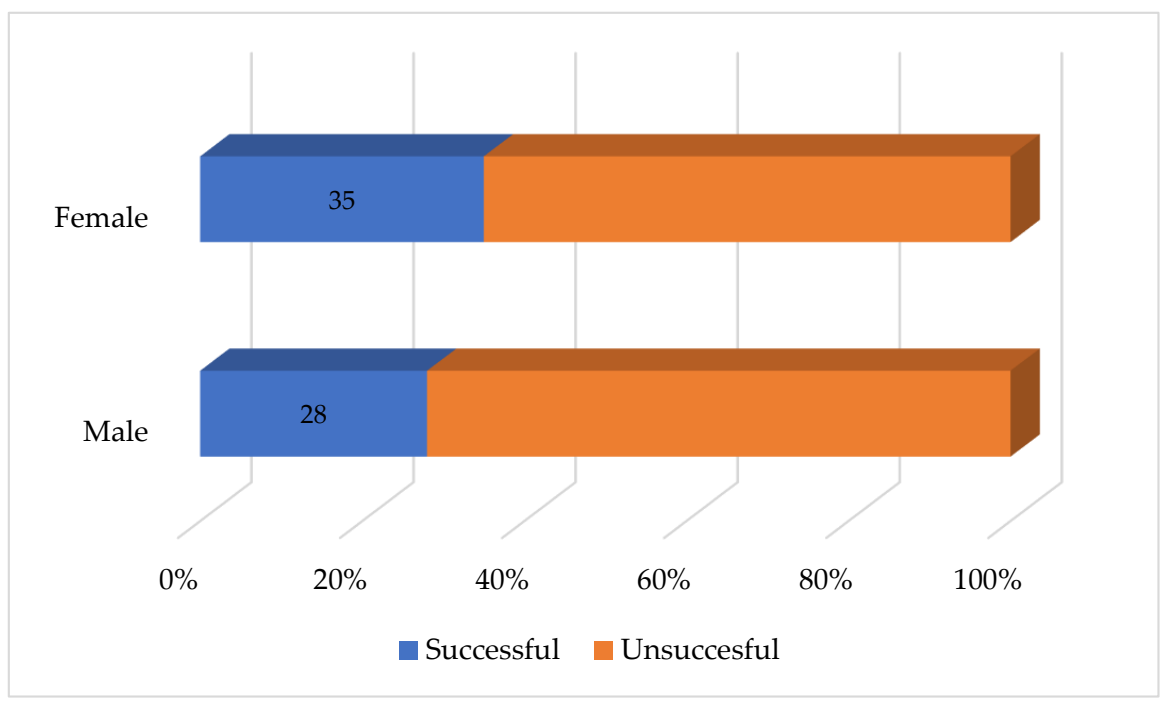

Figure 9. Success rate by sex. 
The findings regarding the differences between the members of two sexes in terms of successful outcomes in accessing subsidies to start their business show a higher success rate among women than men, which comes in accordance with previous findings about the higher performance of firms led by women [12].

\subsection{Results Regarding the Differences in Personality Structure among Successful and Unsuccessful} Nascent Entrepreneurs

Regarding the personality traits of the participants at the study, we sought to identify if there are significant differences between the nascent entrepreneurs who have won the competition and those who have not. Therefore, we analyzed the differences between the mean scores achieved by the members of the two groups for each of the traits assessed. We used independent samples t-test from SPSS (Statistical Package for the Social Sciences) version 23.00 to test the differences between these two categories of nascent entrepreneurs in relation to the variables related to personal characteristics.

However, for most of the traits assessed, we observed variability of the mean score between the two groups, and significant differences were recorded just for some of them.

Table 6 presents the results of the $\mathrm{t}$-test calculated for the two groups for all the ability and personal characteristics assessed in the entrepreneurs who participated in the study. Those dimensions for which significant differences were recorded are signaled in the table and are presented and discussed below.

Table 6. Differences in personal characteristics of successful and unsuccessful nascent entrepreneurs.

\begin{tabular}{|c|c|c|c|c|c|}
\hline Variable & $\begin{array}{c}\text { Criteria } \\
\text { Outcome of the } \\
\text { Competition }\end{array}$ & $\mathbf{N}$ & Mean & SD & $\mathrm{t} / p$ \\
\hline \multicolumn{6}{|c|}{ Entrepreneur Self-Efficacy (ESE) } \\
\hline \multirow{2}{*}{ ESE_searching * } & Successful & 39 & 13.08 & 1.99 & \multirow{2}{*}{$\begin{array}{c}3.49 \\
p=0.001\end{array}$} \\
\hline & Unsuccessful & 84 & 11.31 & 2.85 & \\
\hline \multirow{2}{*}{ ESE_planning * } & Successful & 39 & 16.79 & 3.07 & \multirow{2}{*}{$\begin{array}{c}2.82 \\
p=0.005\end{array}$} \\
\hline & Unsuccessful & 84 & 14.93 & 3.55 & \\
\hline \multirow{2}{*}{ ESE_marshalling * } & Successful & 39 & 13.13 & 2.12 & \multirow{2}{*}{$\begin{array}{c}2.81 \\
p=0.006\end{array}$} \\
\hline & Unsuccessful & 84 & 11.69 & 2.84 & \\
\hline \multirow{2}{*}{ ESE_implementation people * } & Successful & 39 & 26.18 & 3.90 & \multirow{2}{*}{$\begin{array}{c}2.25 \\
p=0.026\end{array}$} \\
\hline & Unsuccessful & 84 & 24.13 & 5.00 & \\
\hline \multirow{2}{*}{ ESE_implementation financial * } & Successful & 39 & 12.08 & 2.75 & \multirow{2}{*}{$\begin{array}{c}2.01 \\
p=0.047\end{array}$} \\
\hline & Unsuccessful & 84 & 10.94 & 2.99 & \\
\hline \multirow{2}{*}{ ESE_total * } & Successful & 39 & 81.26 & 12.46 & \multirow{2}{*}{$\begin{array}{c}2.93 \\
p=0.004\end{array}$} \\
\hline & Unsuccessful & 84 & 73.00 & 15.35 & \\
\hline \multirow{2}{*}{ ESE_EA * } & Successful & 39 & 14.31 & 1.36 & \multirow{2}{*}{$\begin{array}{c}2.66 \\
p=0.009\end{array}$} \\
\hline & Unsuccessful & 84 & 13.32 & 2.12 & \\
\hline \multicolumn{6}{|c|}{ Need for Autonomy } \\
\hline \multirow{2}{*}{ Need for autonomy } & Successful & 39 & 21.92 & 4.44 & \multirow{2}{*}{$\begin{array}{c}0.37 \\
p=0.713\end{array}$} \\
\hline & Unsuccessful & 84 & 21.59 & 4.64 & \\
\hline \multicolumn{6}{|c|}{ The Problem-Solving Inventory (PSI) } \\
\hline \multirow{2}{*}{ PSI_PSC * } & Successful & 39 & 21.87 & 11.25 & \multirow{2}{*}{$\begin{array}{c}-2.34 \\
p=0.02\end{array}$} \\
\hline & Unsuccessful & 84 & 26.79 & 10.60 & \\
\hline \multirow{2}{*}{ PSI_AAS * } & Successful & 39 & 43.05 & 13.05 & \multirow{2}{*}{$\begin{array}{c}-2.55 \\
p=0.01\end{array}$} \\
\hline & Unsuccessful & 84 & 49.81 & 13.90 & \\
\hline \multirow{2}{*}{ PSI_PC } & Successful & 39 & 13.05 & 5.25 & \multirow{2}{*}{$\begin{array}{c}-1.86 \\
p=0.06\end{array}$} \\
\hline & Unsuccessful & 84 & 15.04 & 5.59 & \\
\hline \multirow{2}{*}{ PSI_total * } & Successful & 39 & 77.97 & 26.02 & \multirow{2}{*}{$\begin{array}{c}-2.57 \\
p=0.01\end{array}$} \\
\hline & Unsuccessful & 84 & 91.63 & 27.98 & \\
\hline
\end{tabular}


Table 6. Cont.

\begin{tabular}{|c|c|c|c|c|c|}
\hline Variable & $\begin{array}{l}\text { Criteria } \\
\text { Outcome of the } \\
\text { Competition }\end{array}$ & $\mathbf{N}$ & Mean & SD & $\mathrm{t} / p$ \\
\hline \multicolumn{6}{|c|}{ Tolerance of Ambiguity Scale (TAS) } \\
\hline \multirow{2}{*}{ TAS } & Successful & 39 & 38.38 & 4.76 & \multirow{2}{*}{$\begin{array}{c}0.33 \\
p=0.737\end{array}$} \\
\hline & Unsuccessful & 84 & 38.03 & 5.60 & \\
\hline \multicolumn{6}{|c|}{ Risk Propensity Scale (RPS) } \\
\hline \multirow{2}{*}{ RPS } & Successful & 39 & 31.69 & 6.40 & \multirow{2}{*}{$\begin{array}{c}0.30 \\
p=0.761\end{array}$} \\
\hline & Unsuccessful & 84 & 31.32 & 6.21 & \\
\hline \multicolumn{6}{|c|}{ Psychological Capital (PsyCap) } \\
\hline \multirow{2}{*}{ PsyCap_Hope } & Successful & 39 & 4.95 & 0.71 & \multirow{2}{*}{$\begin{array}{c}1.40 \\
p=0.16\end{array}$} \\
\hline & Unsuccessful & 84 & 4.73 & 0.88 & \\
\hline \multirow{2}{*}{ PsyCap_Optimism } & Successful & 39 & 4.68 & 0.74 & \multirow{2}{*}{$\begin{array}{c}0.48 \\
p=0.63\end{array}$} \\
\hline & Unsuccessful & 84 & 4.61 & 0.77 & \\
\hline \multirow{2}{*}{ PsyCap_Resilience } & Successful & 39 & 5.04 & 0.70 & \multirow{2}{*}{$\begin{array}{c}1.54 \\
p=0.12\end{array}$} \\
\hline & Unsuccessful & 84 & 4.81 & 0.81 & \\
\hline \multirow{2}{*}{ PsyCap_Self-efficacy * } & Successful & 39 & 5.42 & 0.73 & \multirow{2}{*}{$\begin{array}{c}2.09 \\
p=0.03\end{array}$} \\
\hline & Unsuccessful & 84 & 5.08 & 1.01 & \\
\hline \multirow{2}{*}{ PsyCap_Total } & Successful & 39 & 5.02 & 0.59 & \multirow{2}{*}{$\begin{array}{c}1.55 \\
p=0.12\end{array}$} \\
\hline & Unsuccessful & 84 & 4.81 & 0.77 & \\
\hline \multicolumn{6}{|c|}{ Barratt Impulsiveness Scale (BIS-11) } \\
\hline \multirow{2}{*}{ BIS-11 } & Successful & 39 & 59.66 & 8.30 & \multirow{2}{*}{$\begin{array}{c}0.27 \\
p=0.787\end{array}$} \\
\hline & Unsuccessful & 84 & 59.13 & 10.94 & \\
\hline \multicolumn{6}{|c|}{ The Interpersonal Reactivity Index (IRI) } \\
\hline \multirow{2}{*}{ IRI_PT } & Successful & 39 & 19.00 & 4.32 & \multirow{2}{*}{$\begin{array}{c}0.60 \\
p=0.547\end{array}$} \\
\hline & Unsuccessful & 84 & 18.47 & 4.53 & \\
\hline \multirow{2}{*}{ IRI_EC } & Successful & 39 & 18.66 & 4.89 & \multirow{2}{*}{$\begin{array}{c}-0.24 \\
p=0.809\end{array}$} \\
\hline & Unsuccessful & 84 & 18.88 & 4.40 & \\
\hline \multirow{2}{*}{ IRI_PD } & Successful & 39 & 7.66 & 4.43 & -1.516 \\
\hline & Unsuccessful & 84 & 9.04 & 4.82 & $p=0.132$ \\
\hline Adaptat & ind Aggressive Ass & hess & (AAA-S & & \\
\hline AAA-S A orressive ascertiveness & Successful & 39 & 37.15 & 11.16 & 1.62 \\
\hline 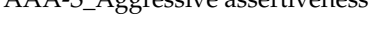 & Unsuccessful & 84 & 33.85 & 10.18 & $p=0.106$ \\
\hline AAA_S Adantive ascertiveness * & Successful & 39 & 58.56 & 7.77 & 2.06 \\
\hline 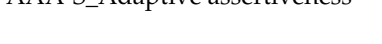 & Unsuccessful & 84 & 55.21 & 9.60 & $p=0.042$ \\
\hline & reneurial Intention & onn & IQ) & & \\
\hline FIO PA & Successful & 39 & 25.36 & 3.77 & 1.582 \\
\hline DIC_t & Unsuccessful & 84 & 23.95 & 4.92 & $p=0.116$ \\
\hline FIO SN & Successful & 39 & 18.54 & 2.65 & 0.332 \\
\hline & Unsuccessful & 84 & 18.35 & 3.16 & $p=0.741$ \\
\hline $\mathrm{FIO} P \mathrm{PBC}^{*}$ & Successful & 39 & 35.95 & 5.99 & 2.84 \\
\hline EIV_t & Unsuccessful & 84 & 31.60 & 8.65 & \\
\hline
\end{tabular}

* Personal characteristics which showed significant differences between the mean scores.

The traits for which no significant differences in the mean scores of the two groups were recorded are: The need for autonomy, tolerance of ambiguity, risk-taking propensity, impulsivity, and interpersonal reactivity.

The personal characteristics which showed significant differences between the mean scores of the two groups are as follows. 


\subsubsection{Entrepreneurial Self-Efficacy}

As mentioned previously, entrepreneurial self-efficacy is a construct that measures a person's confidence in their ability to successfully launch a business [22]. This characteristic of entrepreneurs appears as a particularly important antecedent in the implementation of entrepreneurial intentions $[29,52,80]$ and is useful because it incorporates both personality and external factors, being considered a strong predictor for entrepreneurial intentions and their subsequent implementation [29,81]. Moreover, recent research indicates that the level of entrepreneurial self-efficacy of individuals can be developed through training and education, thus contributes to improving the rate of entrepreneurial activities $[52,82,83]$.

The ESE model conceives the entrepreneurial activity as a process, undergoing four distinct phases: (1) Searching, (2) planning, (3) marshalling, and (4) implementing.

The searching phase implies that the entrepreneur is developing a unique idea and/or identifies a special opportunity. This stage is based on the creative talent of the entrepreneurs and their ability to innovate. Entrepreneurs, unlike managers, are particularly skilled to perceive and exploit opportunities before these opportunities are recognized by others [84].

The planning phase consists of activities through which the entrepreneur converts the idea into a feasible business plan. At this stage, the entrepreneur may or may not write a formal business plan. However, he or she must evaluate the business idea or concept and give it substance as a business [83].

The marshalling phase involves gathering the available resources to start the business. At the end of the planning phase, the business is only "on paper" or in the mind of the entrepreneur. To start a business, the entrepreneur gathers (mobilizes, collects) the necessary resources, such as financial resources, the labor force, customers, and suppliers, without which the business cannot exist or cannot be sustained [83].

In the final phase of implementation, the entrepreneur is responsible for growing and supporting the business throughout its development. Towards this goal, the successful entrepreneur applies quality management skills and principles. As an executive manager, the entrepreneur is involved in strategic planning and manages a variety of business relationships with suppliers, customers, employees, and capital providers. Developing a business requires vision and the ability to solve problems quickly and efficiently. These tasks are not only characteristic of the entrepreneur but are also necessary for efficient managers. However, the entrepreneur is the main risk-taker of the enterprise, with a financial interest for the growth and long-term success of the business [83]. The tasks associated with the implementation phase are divided into two categories to make a clear distinction between "people-related" tasks and "financial" tasks of running a small business.

The analysis included additionally a scale that measures the attitude towards entrepreneurship/starting a business (EA). The items in the EA subscale refer to the utility, satisfaction, and general attitude of the respondents about starting their own business.

The results of the t-test on ESE scale show significant differences between the two groups on all five subscales-Searching $(t=3.049, p<0.05)$, Planning $(t=2.82, p<0.05)$, Marshalling $(t=2.81, p<0.05)$, Implementation-people $(t=2.25, p<0.05)$, and Implementation-financial $(t=2.01, p<0.047)$. Also, the total score on the ESE scale registers significant differences $(t=2.99, p<0.05)$, with 81.26 mean for the successful entrepreneurs, compared with 73.00 for the unsuccessful ones. Additionally, the extra dimension of Entrepreneurial Attitude reveals significant differences between the two groups $(t=2.66$, $p<0.05)$.

Therefore, the successful entrepreneurs participating in the study showed much more confidence in their capacity to manage every phase of the business creation process and a more positive attitude towards entrepreneurship, compared to their unsuccessful counterparts. 


\subsubsection{The Problem-Solving Capacity}

Applied problem solving is a very complex, often intermittent, goal-oriented sequence of cognitive, affective, and behavioral operations performed by the individual to adapt to internal or external demands that are often considered stressful [62,65].

The inventory used measures people's perception of their problem-solving ability and style considering three factors: (1) Problem-solving confidence, (2) Approach-Avoidance Style, and (3) Personal control. Each aspect provides an evaluation of a specific dimension of the problem-solving style, and the overall score reflects the individual's overall assessment of his or her problem-solving style.

The $t$-test results of the scores to the Problem-Solving Inventory reveal significant differences between the two groups for the total score $(t=-2.57, p<0.05)$ and two out of the three items: Problem Solving Confidence $(t=-2.34, p<0.05)$ and Approach-Avoidance Style $(t=-2.55, p<0.05)$.

Problem-solving confidence (PSC) is defined as self-assurance, belief, and trust of each person in their ability to deal effectively with a wide range of problems. Due to the way items are rated, lower PSC scores reflect higher levels of problem-solving confidence. Thus, among the successful entrepreneurs, the mean score on this subscale (21.87) is lower than for the unsuccessful ones (26.79), which translates into increased confidence among the former in their ability to solve problems.

Approach-Avoidance Style (AAS) refers to a general tendency to approach or avoid various problem-solving activities. Lower scores are associated with a confrontational style and higher scores with avoiding problems. Thus, analyzing the differences between the two groups, we notice that the successful entrepreneurs have a lower mean score on this subscale (43.05) than that of the unsuccessful entrepreneurs (49.81), which means that they tend to confront the problems rather than to avoid them.

Low scores for each factor (and, therefore, for the total PSI score) are generally considered more functional. The analysis of the results shows that the successful entrepreneurs had a significantly lower mean score (77.97) than the unsuccessful ones (91.63), which means that they have more functional ways and styles of working when it comes to problem-solving.

Therefore, the successful entrepreneurs differ from those who did not win the competition in terms of problem-solving abilities, especially regarding their problem-solving confidence and their tendency to deal with problems instead of avoiding them.

\subsubsection{Psychological Capital}

The Psychological capital is a state-type psychological variable that includes four personal resources: Hope, optimism, resilience, and self-efficacy.

The t-test results show significant differences between the two groups only for the self-efficacy component. Thus, for the successful entrepreneurs, the mean value for Self-efficacy scores (5.42) is significantly higher $(t=2.09, p<0.05)$ than for the unsuccessful ones (5.08).

Self-efficacy is defined as a person's belief in his or her ability to mobilize the motivation, cognitive resources, and course of action that are needed to perform a specific action in a given context [85]. Therefore, the successful entrepreneurs in the sample differ from the unsuccessful ones in terms of self-efficacy, by showing higher levels of trust in their ability to carry out work-related tasks.

\subsubsection{Assertiveness}

Assertiveness describes an active response to interpersonal conflicts, applied to ensure the fulfillment of personal needs [78].

There are two possible types of assertive responses: Aggressive assertiveness, which implies the use of coercive behavior or violation of the rights of others in the process of ensuring needs satisfaction; and adaptive assertiveness, which reflects the use of socially acceptable behaviors, without violating the rights of others, in the process of ensuring needs satisfaction [78]. 
The analysis of the AAA-S results shows higher scores for the successful entrepreneurs on both types of assertive responses, but only significant for Adaptative assertiveness $(t=2.06, p<0.05)$. Therefore, the successful entrepreneurs from the sample differ from the unsuccessful ones in terms of improved capacity to solve potential conflicts and ensure the satisfaction of their needs by using socially acceptable behaviors.

\subsubsection{Entrepreneurial Intention}

The entrepreneurial intention refers to the effort a person is willing to make to achieve their business goals [24]. The EIQ is composed of three motivational (or antecedent) factors that influence behavior: Personal attitude, subjective norm, and perceived behavioral control.

Results reveal a significant difference between the two groups on Perceived Behavioral Control $(t=2.84, p<0.05)$, with higher means for winners (35.95) than for non-winners (31.60) and no significant differences for the other two variables from the EIQ (Personal Attitude and Subjective Norms).

Perception of behavioral control (PBC) is defined as the perception of the ease or difficulty of becoming an entrepreneur. It is, therefore, a concept quite similar to self-efficacy (SE) [86] and perceived feasibility [87]. All three concepts refer to the feeling of being capable of contributing to the development of an entrepreneurial initiative. PBC not only includes the feeling of being capable but also the perception of controllable behavior. Therefore, according to the data, successful entrepreneurs in the sample have, on average, greater confidence in their ability to control their entrepreneurial behavior and take the necessary steps to set up and run a business, compared to the unsuccessful entrepreneurs.

\section{Discussion}

Small and medium-sized enterprises (SMEs) play a crucial role in generating economic growth, job creation, and sustainable development. In this type of entity, the entrepreneur is a critical agent for the survival and success of the business $[14,15,41]$.

Based on this premise, a great deal of scholarly effort was dedicated to the assessment of the influence the personal characteristics of entrepreneurs on the success of their businesses $[9,12,13,17-20,46,48,50,51,53,88]$. The character-based approach takes into account the human capital and the personality structure of the entrepreneurs, associated with positive outcomes of the entrepreneurial endeavor. Empirical studies conducted based on this approach $[13,18,19,53]$ have identified various personality traits of entrepreneurs associated with entrepreneurial success. These characteristics can impact entrepreneurial activity positively (creating the premises for entrepreneurial success) or negatively (hindering the chances for success by directing the entrepreneur to behaviors that undermine successful activities).

In the current study, we used a processual approach of entrepreneurial activity [24], taking into consideration three distinct stages involved in the process of setting up a new business.

Starting from the enactment of the entrepreneurial intention, by the nascent entrepreneurs involved in the study, through their enrolment in the entrepreneurial support program, we have assessed their profiles (human capital and personality structure) and followed up their outcomes in trying to secure the funding of their business plan. Securing the subsidy for starting their new business was considered the first sign of entrepreneurial success, and the subsequent analysis of the data sought to answer the research question What are the personal characteristics that distinguish successful entrepreneurs from the unsuccessful ones?

Regarding the characteristics related to the human capital of the participants at the study, the results align with those of previous studies [12,17], showing that, although the level of education held by the nascent urban entrepreneurs participating in the study is consistently higher compared to that of the general population, the success rate registered in the competition by those with lower levels of educational attainment is similar to the one registered by those with higher levels of educational attainment. 
The association between entrepreneurial success and the length of professional experience held by attendants at the study showed that, while for those who had a very low level of work experience (less than one year) the outcomes in the competition were the worst, for the other groups, the success rate din not necessarily show an increase that would correspond with the increasing length of work experience.

Also, in terms of age, the results of the study showed that the youngest ( 25 or under) and the oldest (over 45) entrepreneurs had the lowest success rates. In contrast, the ones in the middle categories (26 to 35 and 36 to 45 ) were considerably more successful. These findings confirm the results of similar studies, which recorded good potential for success both among younger entrepreneurs [49] and among middle-aged ones [50].

Additionally, the analysis of the success rate by sex showed a slightly higher success rate among women (35\%) than among men $(28 \%)$, which is in line with previous findings of the higher performance of firms led by women [12], but also with the observation that the inter-sex differences in terms of entrepreneurial results are small [20].

Regarding the personality structure of the entrepreneurs involved in the study, the analysis of the results showed that, although most of the characteristics assessed showed variability of the mean score between the two groups (successful and unsuccessful entrepreneurs), the differences were only statistically significant in some.

The personal characteristics for which no statistically significant differences in the mean scores of the two groups were recorded are: The need for autonomy, tolerance of ambiguity, risk-taking propensity, impulsivity, and interpersonal reactivity. A key in which this finding can be interpreted is the following: The need for autonomy, the tolerance of ambiguity, the risk-taking propensity, and the impulsivity are considered pre-requisites of the crystallization of the entrepreneurial intention, meaning they support the individual to take the decision to start a business on their own. However, since all the participants at the study already had a crystalized EI, proven by the fact that they engaged in the support program, it could mean that these traits no longer hold a significant influence after the intention was enacted. It could be that these traits differentiate the entrepreneurs from other types of populations (such as managers or employees), but not among themselves. As for the influence of interpersonal reactivity (empathy), it is possible that this trait might have an influence at a later stage in the entrepreneurial process, when it helps the entrepreneur relate to the customers' needs and adapt to the market changes.

The characteristics for which statistically significant differences were recorded are motivational traits (entrepreneurial self-efficacy), cognitive skills (problem-solving orientation), affective personality traits (Psychological capital, and more specifically, self-efficacy), and social skills (assertiveness).

Thus, the results of the comparison showed that, compared to their unsuccessful counterparts, the successful nascent entrepreneurs in the sample had:

- Increased levels of entrepreneurial self-efficacy for each phase of the entrepreneurial process (searching; planning; marshalling; and implementing) and a more positive attitude towards entrepreneurship;

- Increased levels of problem-solving confidence and the tendency to deal with problems instead of avoiding them;

- Higher levels of trust in their capacity of taking up challenges; this type of trust can have a bi-directional relationship with success, feeding it, but also feeding from it;

- Increased levels of assertiveness, with a focus on solving potential conflicts by using socially acceptable behaviors to ensure the satisfaction of their needs;

- Greater confidence in their ability to control their entrepreneurial behavior and take the necessary steps to set up and run a business, compared to the unsuccessful entrepreneurs.

These findings help shed some light on the way these traits can influence the success of the nascent entrepreneurs at this stage of the entrepreneurial process: 
The increased levels of entrepreneurial self-efficacy in searching, planning, and marshalling, the more positive attitude towards entrepreneurship, and the higher levels of problem-solving confidence were useful for the entrepreneurs in documenting for the business plan, and developing it with increased attention to details regarding product/service detail, pricing levels, or operational aspects. This, in turn, would reflect on the quality of their business plan.

The increased levels of entrepreneurial self-efficacy in implementing the business plan, increased trust in their capacity of taking up challenges, and increased confidence in their ability to control their entrepreneurial behavior would help the entrepreneurs in identifying the potential risks to their endeavor and planning the strategies to overcome them, which reflects on the feasibility of the business plan, as assessed by the panel of jurors.

Additionally, the increased levels of adaptive assertiveness may have come in handy during the interview phase of the competition, helping the successful entrepreneurs communicate better than their counterparts with the jurors and possibly making a better overall impression.

A possible interpretation of these findings would be that the personal characteristics of entrepreneurs that help them achieve success in their endeavors may depend on which stage in their entrepreneurial career they find themselves.

Moreover, the results of the comparison between successful and unsuccessful nascent entrepreneurs show that, early on in the entrepreneurial career, the characteristics that influence entrepreneurial success are mainly malleable and can be modelled, with appropriate support, training, counselling, and guidance, into desirable traits that increase the chances of success for both the entrepreneurs and their newly established firms.

Therefore, it would be advisable, for future similar entrepreneurial support programs to also include, among their usual services (such as training, counselling, mentorship), dedicated to improving entrepreneurial skills, some personal development activities, aimed at enhancing the confidence of the nascent entrepreneurs in their own capacities of setting up the newly established business.

\section{Limitations of the Study}

The main limitation of the current study stems from the data collection method used, which was an online questionnaire. It is commonly accepted that in online data collection the participation rates are low compared to those in traditional pencil-and-paper surveys [89]. Also, research showed that longer surveys (such as ours-207 items in total) have lower completion rates [90]. This would explain the lower response rate to our invitation to participate in the study (20.5\% response rate). However, the fact that the respondents that completed the questionnaire chose to participate voluntarily reflects positively on the quality of the responses [89].

Another issue relates to the fact that, in internet surveys, the selection of a proper probability sample requires a sampling frame containing the e-mail addresses of all individuals in the population [91], which is rarely the case. Additionally, the potential respondents that do not have internet access will also not participate [91]. However, ours was somewhat of a fortunate case, since all the participants in the entrepreneurial support program registered with the two scheme administrators had access to internet and had a valid email account (which was the main communication instrument with the scheme administrators). Also, the invitation to participate in the study was sent to all the participants registered in the support program.

Although the results of the study come in line with the findings of previous similar research, due to the limitations posed by the data collection method used in the current study, we would not advise generalizing the results to a larger population (such as the nascent entrepreneur population in Romania). Additionally, due to the specificities of the government sponsored entrepreneurial support program, which supported only non-agricultural start-ups, set up in urban areas, we would also advise against inferring the results of the current study to a population of entrepreneurs with a different profile (i.e., rural entrepreneurs or experienced entrepreneurs). 
We would argue, however, for the replication of the current study in different cultural contexts, in order to be able to advance the understanding of the personal characteristics of entrepreneurs that host the potential for entrepreneurial success, at the onset of the entrepreneurial career.

Author Contributions: Conceptualization, E.-L.B. and D.V.; methodology, E.-L.B. and D.V.; software, E.-L.B. and D.V.; validation, D.V.; formal analysis, D.V. and T.-A.L.; investigation, E.-L.B. and D.V.; resources, E.-L.B. and T.-A.L.; data curation, E.-L.B., D.V. and T.-A.L.; writing-original draft preparation, E.-L.B. and D.V.; writing-review and editing, E.-L.B. and T.-A.L.; visualization, E.-L.B. and T.-A.L.; supervision, E.-L.B.; project administration, E.-L.B.; funding acquisition, E.-L.B. and T.-A.L. All authors have read and agreed to the published version of the manuscript.

Funding: This research was funded by The European Social Fund through the Operational Program Human Capital 2014-2020, grant number POCU/82/3/7/104013. The APC was funded by the West University of Timișoara.

Conflicts of Interest: The authors declare no conflict of interest.

\section{Abbreviations}

\section{AAA-S}

AAA-S_Adaptive assertiveness

AAA-S_Aggressive assertiveness

BA

BIS-11

EI

EIQ

EIQ_PA

EIQ_PBC

EIQ_SN

ESE

ESE_EA

ESE_implementation financial

ESE_implementation people

ESE_marshalling

ESE_searching

GDP

IRI

IRI_EC

IRI_PD

IRI_PT

ISCED

PSI

PSI_AAS

PSI_PC

PSI_PSC

PsyCap

PsyCap Hope

PsyCap_Optimism

PsyCap_Resilience

PsyCap_Self-efficacy

RPS

SME(s)

SPSS

TAS

W-BNS
Adaptive and Aggressive Assertiveness Scales

Subscale of AAA-S

Subscale of AAA-S

Bachelor (Educational level)

The Barratt Impulsiveness Scale

Entrepreneurial intention

Entrepreneurial Intention Questionnaire

Personal Attitude (Subscale of EIQ)

Perceived Behavioral Control (Subscale of EIQ)

Subjective Norm (Subscale of EIQ)

Entrepreneurial Self-Efficacy (Scale)

Entrepreneurial attitude (Subsclae of ESE)

Subscale of ESE

Subscale of ESE

Subscale of ESE

Subscale of ESE

Gross domestic product

The Interpersonal Reactivity Index

Empathic Concern (Subscale of IRI)

Personal Distress (Subscale of IRI)

Perspective Taking (Subscale of IRI)

The International Standard Classification of Education

The Problem-Solving Inventory (Scale)

Approach-Avoidance Style (Subscale of PSI)

Personal Control (Subscale of PSI)

Problem Solving Confidence (Subscale of PSI)

The Psychological Capital Questionnaire

Subscale of PsyCap

Subscale of PsyCap

Subscale of PsyCap

Subscale of PsyCap

Risk Propensity Scale

Small and medium-sized entreprise(s)

Statistical Package for the Social Sciences

Tolerance of Ambiguity Scale

Work-related Basic Need Satisfaction Scale 


\section{References}

1. Chinitz, B. Contrasts in Agglomeration: New York and Pittsburgh. Am. Econ. Rev. Pap. Proc. 1961, 51, 279-289.

2. Saxenian, A. Regional Advantage: Culture and Competition in Silicon Valley and Route 128; Harvard University Press: Cambridge, MA, USA, 1994.

3. Glaeser, E.L.; Kerr, S.P.; Kerr, W.R. Entrepreneurship and Urban Growth: An Empirical Assessment with Historical Mines, Working Paper 18333. NBER Work. Pap. Ser. 2012. [CrossRef]

4. Delgado, M.; Porter, M.; Stern, S. Clusters and Entrepreneurship. J. Econ. Geogr. 2010, 10, 495-518. [CrossRef]

5. Bosma, N.; Sternberg, R. Entrepreneurship as an urban event? Empirical evidence from European cities. Reg. Stud. 2014, 48, 1016-1033. [CrossRef]

6. Diabate, A.; Sibiri, H.; Wang, L.; Yu, L. Assessing SMEs' Sustainable Growth through Entrepreneurs' Ability and Entrepreneurial Orientation: An Insight into SMEs in Côte d'Ivoire. Sustainability 2019, 11, 7149. [CrossRef]

7. Howell, A.; He, C.; Yang, R.; Fan, C.C. Agglomeration, (un)-related variety and new firm survival in China: Do local subsidies matter? Pap. Reg. Sci. 2018, 97, 485-500. [CrossRef]

8. Kluve, J.; Puerto, S.; Robalino, D.; Romero, J.M.; Rother, F.; Stoeterau, J.; Weidenkaff, F.; Witte, M. Interventions to improve the labour market outcomes of youth: A systematic review of training, entrepreneurship promotion, employment services and subsidized employment interventions. Campbell Syst. Rev. 2017, 13, 1-288. [CrossRef]

9. Caliendo, M.; Kritikos, A.S. Is entrepreneurial success predictable? An ex-ante analysis of the character-based approach. Kyklos 2008, 61, 189-214. [CrossRef]

10. Helmers, C.; Rogers, M. Innovation and the survival of new firms in the UK. Rev. Ind. Organ. 2010, 36, 227-248. [CrossRef]

11. Quatraro, F.; Vivarelli, M. Drivers of entrepreneurship and post-entry performance of newborn firms in developing countries. World Bank Res. Obs. 2015, 30, 277-305. [CrossRef]

12. Why Are Optimistic Entrepreneurs Successful? An Application of the Regulatory Focus Theory RePEc 2008. Available online: https:/deepblue.lib.umich.edu/bitstream/handle/2027.42/64399/wp914.pdf (accessed on 26 May 2020).

13. Brandstätter, H. Personality aspects of entrepreneurship: A look at five meta-analyses. Personal. Individ. Differ. 2011, 51, 222-230. [CrossRef]

14. Levine, R.; Rubinstein, Y. Smart and illicit: Who becomes an entrepreneur and do they earn more? Q. J. Econ. 2017, 132, 963-1018. [CrossRef]

15. Manso, G. Experimentation and the returns to entrepreneurship. Rev. Financ. Stud. 2016, 29, $2319-2340$. [CrossRef]

16. King, A.S. Self-analysis and assessment of entrepreneurial potential. Simul. Games 1985, 16, 399-416. [CrossRef]

17. Robinson, P.B.; Sexton, E.A. The effect of education and experience on self-employment success. J. Bus. Ventur. 1994, 9, 141-156. [CrossRef]

18. Baron, R.A. Psychological perspectives on entrepreneurship: Cognitive and social factors in entrepreneurs' success. Curr. Dir. Psychol. Sci. 2000, 9, 15-18. [CrossRef]

19. Leutner, F.; Ahmetoglu, G.; Akhtar, R.; Chamorro-Premuzic, T. The relationship between the entrepreneurial personality and the Big Five personality traits. Pers. Individ. Differ. 2014, 63, 58-63. [CrossRef]

20. Akhtar, R.; Ahmetoglu, G.; Chamorro-Premuzic, T. Greed is good? Assessing the relationship between entrepreneurship and subclinical psychopathy. Personal. Individ. Differ. 2013, 54, 420-425. [CrossRef]

21. Dimov, D. Nascent Entrepreneurs and Venture Emergence: Opportunity Confidence, Human Capital, and Early Planning. J. Manag. Stud. 2010, 47, 1123-1153. [CrossRef]

22. McGee, J.E.; Peterson, M.; Mueller, S.L.; Sequeira, J.M. Entrepreneurial self-efficacy: Refining the measure. Entrep. Theory Pract. 2009, 33, 965-988. [CrossRef]

23. Aldrich, H.E.; Martinez, M.A. Many are called, but few are chosen: An evolutionary perspective for the study of entrepreneurship. Entrep. Theory Pract. 2001, 25, 41-56. [CrossRef]

24. Liñán, F.; Chen, Y.W. Development and cross-cultural application of a specific instrument to measure entrepreneurial intentions. Entrep. Theory Pract. 2009, 33, 593-617. [CrossRef] 
25. Fishbein, M.; Ajzen, I. Belief, Attitude, Intention and Behavior: An Introduction to Theory and Research; Addison-Wesley: New York, NY, USA, 1975.

26. Lee, S.H.; Wong, P.K. An exploratory study of technopreneurial intentions: A career anchor perspective. J. Bus. Ventur. 2004, 19, 7-28. [CrossRef]

27. Ajzen, I. The theory of planned behavior. Organ. Behav. Hum. Decis. Process. 1991, 50, 179-211. [CrossRef]

28. Liñán, F. Intention-based models of entrepreneurship education. Piccola Impresa Small Bus. 2004, 2004, 11-35.

29. Boyd, N.; Vozikis, G. The influence of self-efficacy on the development of entrepreneurial intentions and actions. Entrep. Theory Pract. 1994, 18, 63-77. [CrossRef]

30. Brush, C.G.; Ceru, D.J.; Blackburn, R. Pathways to entrepreneurial growth: The influence of management, marketing, and money. Bus. Horiz. 2009, 52, 481-491. [CrossRef]

31. Robinson, K. An examination of the influence of industry structure on eight alternative measures of new venture performance for high potential independent new ventures. J. Bus. Ventur. 1999, 14, 165-187. [CrossRef]

32. Vesper, K. New Venture Experience; Vector Books: Seattle, WA, USA, 1996.

33. Delmar, F.; Davidsson, P.; Gartner, W. Arriving at the high-growth firm. J. Bus. Ventur. 2003, 18, $189-216$. [CrossRef]

34. Headd, B. Redefining Business Success: Distinguishing between Closure and Failure. Small Bus. Econ. 2003, 21, 51-61. [CrossRef]

35. Brinckmann, J.; Grichnik, D.; Kapsa, D. Should Entrepreneurs Plan or Just Storm the Castle? A Meta-Analysis on Contextual Factors Impacting the Business Planning-Performance Relationship in Small Firms. J. Bus. Ventur. 2010, 25, 24-40. [CrossRef]

36. Wennberg, K.; Wiklund, J.; DeTienne, D.R.; Cardon, M.S. Reconceptualizing Entrepreneurial Exit: Divergent Exit Routes and Their Drivers. J. Bus. Ventur. 2010, 25, 361-375. [CrossRef]

37. Parker, S.C.; Belghitar, Y. What Happens to Nascent Entrepreneurs? An Econometric Analysis of the PSED. Small Bus. Econ. 2006, 27, 81-101. [CrossRef]

38. Lukeš, M.; Zouhar, J. The causes of early-stage entrepreneurial discontinuance. Prague Econ. Pap. 2016, 1, 19-36. [CrossRef]

39. Rauch, A.; Frese, M. Psychological Approaches to Entrepreneurial Success: A General Model and an Overview of Findings. In International Review of Industrial and Organizational Psychology; Cooper, C., Robertson, I., Eds.; Wiley: Chichester, UK, 2002; pp. 101-142.

40. Bianchi, M.; Henrekson, M. Is Neoclassical Economics still Entrepreneurless? Kyklos 2005, 58, 353-377. [CrossRef]

41. Obschonka, M.; Stuetzer, M. Integrating psychological approaches to entrepreneurship: The Entrepreneurial Personality System (EPS). Small Bus. Econ. 2017, 49, 203-231. [CrossRef]

42. Laguna, M.; Razmus, W.; Żaliński, A. Dynamic relationships between personal resources and work engagement in entrepreneurs. J. Occup. Organ. Psychol. 2017, 90, 248-269. [CrossRef]

43. Gorgievski, M.J.; Moriano, J.A.; Bakker, A.B. Relating work engagement and workaholism to entrepreneurial performance. J. Manag. Psychol. 2014, 29. [CrossRef]

44. Dai, L.; Maksimov, V.; Gilbert, B.A.; Fernhaber, S.A. Entrepreneurial orientation and international scope: The differential roles of innovativeness, proactiveness, and risk-taking. J. Bus. Ventur. 2014, 29, 511-524. [CrossRef]

45. Hsiao, C.; Lee, Y.H.; Chen, H.H. The effects of internal locus of control on entrepreneurship: The mediating mechanisms of social capital and human capital. Int. J. Hum. Res. Manag. 2016, 27, 1158-1172. [CrossRef]

46. Davidsson, P.; Gordon, S.R. Panel Studies of New Venture Creation: A Methods- Focused Review and Suggestions for Future Research. Small Bus. Econ. 2012, 39, 853-876. [CrossRef]

47. Brüderl, J.; Preisendörfer, P.; Ziegler, R. Survival Chances of Newly Founded Business Organizations. Am. Sociol. Rev. 1992, 57, 227-242. [CrossRef]

48. Lukeš, M.; Zouhar, J. No Experience? No Problem-It's all about yourself: Factors Influencing Nascent Entrepreneurship Outcomes. Ekon. Č. 2013, 61, 934-950.

49. Watson, W.; Stewart, W., Jr.; BarNir, A. The effects of human capital, organizational demography and interpersonal processes on venture partner perceptions of firm profit and growth. J. Bus. Ventur. 2003, 18, 145-164. [CrossRef]

50. Burns, P. Entrepreneurship and Small Business; Palgrave Macmillan: London, UK, 2001. 
51. Cooper, A.; Gimeno-Gascon, J.; Woo, C.Y. Initial human and financial capital as predictors of new venture performance. J. Bus. Ventur. 1994, 9, 371-395. [CrossRef]

52. Zhao, H.; Seibert, C.; Hills, C. The mediating role of self-efficacy in the development of entrepreneurial intentions. J. Appl. Psychol. 2005, 90, 1265-1272. [CrossRef]

53. Caliendo, M.; Fossen, F.; Kritikos, A.S. The personality characteristics and the decision to become and stay self-employed. Small Bus. Econ. 2014, 42, 787-814. [CrossRef]

54. Paunonen, S.V.; Jackson, D.N. What is beyond the Big Five? Plenty! J. Personal. 2000, 68, 821-835. [CrossRef]

55. Ashton, M.C.; Lee, K.; Perugini, M.; Szarota, P.; de Vries, R.E.; Di Blas, L.; De Raad, B. A six-factor structure of personality-descriptive adjectives: Solutions from psycholexical studies in seven languages. J. Personal. Soc. Psychol. 2004, 86, 356-366. [CrossRef]

56. Wu, B.; Knott, A. Entrepreneurial risk and market entry. Manag. Sci. 2006, 52, 1315-1330. [CrossRef]

57. Obschonka, M.; Fisch, C.; Boyd, R. Using digital footprints in entrepreneurship research: A Twitter-based personality analysis of superstar entrepreneurs and managers. J. Bus. Ventur. Insights 2017, 8, 13-23. [CrossRef]

58. Konon, A.; Kritikos, A.S. Prediction based on entrepreneurship-prone personality profiles: Sometimes worse than the toss of a coin. Small Bus. Econ. 2019, 53, 1-20. [CrossRef]

59. Van den Broeck, A.; Vansteenkiste, M.; De Witte, H.; Soenens, B.; Len, W. Capturing autonomy, competence, and relatedness at work: Construction and initial validation of the Work-related Basic Need Satisfaction scale. J. Occup. Organ. Psychol. 2010, 83, 981-1002. [CrossRef]

60. Deci, E.L.; Ryan, R.M. The 'what' and 'why' of goal pursuits: Human needs and the self-determination of behaviour. Psychol. Inquiry 2000, 11, 319-338. [CrossRef]

61. Bekker, M.H.; van Assen, M.A. A short form of the autonomy scale: Properties of the autonomy-connectedness scale (ACS-30). J. Personal. Assess. 2006, 86, 51-60. [CrossRef] [PubMed]

62. Heppner, P.P.; Krauskopf, C.J. An information-processing approach to personal problem solving. Couns. Psychol. 1987, 15, 371-447. [CrossRef]

63. Heppner, P.P.; Petersen, C.H. The development and implications of a personal problem solving inventory. J. Couns. Psychol. 1982, 29, 66-75. [CrossRef]

64. Heppner, P.P. The Problem Solving Inventory (PSI): Research Manual; Consulting Psychologists Press: Palo Alto, CA, USA, 1988.

65. Heppner, P.P.; Witty, T.E.; Dixon, W.A. Problem-Solving Appraisal and Human Adjustment: A Review of 20 Years of Research Using the Problem Solving Inventory. Couns. Psychol. 2004, 32, 344-427. [CrossRef]

66. Herman, J.L.; Stevens, M.J.; Bird, A.; Mendenhall, M.; Oddou, G. The Tolerance for Ambiguity Scale: Towards a more refined measure for international management research. Int. J. Intercult. Relat. 2010, 34, 58-65. [CrossRef]

67. Budner, S. Intolerance of ambiguity as a personality variable. J. Personal. 1962, 30, 29-50. [CrossRef]

68. Meertens, R.M.; Lion, R. Measuring an Individual's Tendency to Take Risks: The Risk Propensity Scale. J. Appl. Soc. Psychol. 2008, 38, 1506-1520. [CrossRef]

69. Luthans, F.; Youssef, C.M.; Avolio, B.J. Psychological Capital: Developing the Human Competitive Edge; Oxford University Press: Oxford, UK, 2007.

70. Patton, J.H.; Stanford, M.S.; Barratt, E.S. Factor structure of the Barratt impulsiveness scale. J. Clin. Psychol. 1995, 6, 768-774. [CrossRef]

71. Moeller, F.G.; Barratt, E.S.; Dougherty, D.M.; Schmitz, J.M.; Swann, A.C. Psychiatric aspects of impulsivity. Am. J. Psychiatry 2001, 158, 1783-1793. [CrossRef] [PubMed]

72. Wiklund, J.; Yu, W.; Tucker, R.; Marino, L.D. ADHD, impulsivity and entrepreneurship. J. Bus. Ventur. 2017, 32, 627-656. [CrossRef]

73. Davis, M.H. A multidimensional approach to individual differences in empathy. Cat. Sel. Doc. Psychol. 1980, 10,85 .

74. Charbonneau, D.; Nicol, A.A.M. Emotional intelligence and prosocial behaviors in adolescents. Psychol. Rep. 2002, 90, 361-370. [CrossRef]

75. Noller, P.; Ruzzene, M. Communication in marriage: The influence of affect and cognition. In Cognitions in Close Relationships; Fletcher, G.J.O., Fincham, F.D., Eds.; Erlbaum: Hillsdale, NJ, USA, 1991; pp. 203-233.

76. Musick, M.A.; Wilson, J. Volunteering and depression: The role of psychological and social resources in different age groups. Soc. Sci. Med. 2003, 56, 259-269. [CrossRef] 
77. Thompson, R.J.; Berenbaum, H. Adaptive and Aggressive Assertiveness Scales (AAA-S). J. Psychopathol. Behav. Assess. 2011, 33, 323-334. [CrossRef]

78. Hollandsworth, J.G. Differentiating assertion and aggression: Some behavioral guidelines. Behav. Therapy 1977, 8, 347-352. [CrossRef]

79. Eurostat. Population Aged 25-64 by Educational Attainment Level, Sex and NUTS 2 Regions. Available online: https://ec.europa.eu/eurostat/web/products-datasets/-/edat_lfse_04 (accessed on 26 May 2020).

80. Barbosa, S.; Gerhardt, M.; Kickul, J. The role of cognitive style and risk preference on entrepreneurial self-efficacy and entrepreneurial intentions. J. Leadersh. Organ. Stud. 2007, 13, 86-104. [CrossRef]

81. Bird, B. Implementing entrepreneurial ideas: The case for intention. Acad. Manag. Rev. 1988, 13, 442-453. [CrossRef]

82. Florin, J.; Karri, R.; Rossiter, N. Fostering entrepreneurial drive in business education: An attitudinal approach. J. Manag. Educ. 2007, 31, 17-42. [CrossRef]

83. Mueller, S.L.; Goic, S. East-West differences in entrepreneurial self-efficacy: Implications for entrepreneurship education in transition economies. Int. J. Entrep. Educ. 2003, 1, 613-632.

84. Hisrich, R.D.; Peters, M.P.; Sheperd, D.A. Entrepreneurship, 6th ed.; McGraw-Hill/Irwin: New York, NY, USA, 2005.

85. Stajkovic, A.D.; Luthans, F. Self-efficacy and work-related performance: A meta-analysis. Psychol. Bull. 1998, 124, 240-261. [CrossRef]

86. Bandura, A. Self-Efficacy: The Exercise of Control; H. Freeman: New York, NY, USA, 1997.

87. Shapero, A.; Sokol, L. Social dimensions of entrepreneurship. In The Encyclopedia of Entrepreneurship; Kent, C., Sexton, D., Vesper, K., Eds.; Prentice-Hall: Englewood Cliffs, NJ, USA, 1982; pp. 72-90.

88. Gimeno, J.; Folta, T.B.; Cooper, A.C.; Woo, C.Y. Survival of the Fittest? Entrepreneurial Human Capital and the Persistence of Underperforming. Adm. Sci. Q. 1997, 42, 750-783. [CrossRef]

89. Lefever, S.; Dal, M.; Matthiasdottir, A. Online data collection in academic research: Advantages and limitations. Br. J. Educ. Technol. 2007, 38, 574-582. [CrossRef]

90. Liu, M.; Wronski, L. Examining completion rates in web surveys via over 25,000 real-world surveys. Soc. Sci. Comput. Rev. 2018, 36, 116-124. [CrossRef]

91. Greenacre, Z.A. The Importance of Selection Bias in Internet Surveys. Open J. Stat. 2016, 6, 397-404. [CrossRef] 